\begin{tabular}{l} 
Missio Ecclesiae \\
ISSN 2086-5368 (Print) \\
ISSN 2721-8198 (Online) \\
https://jurnal.i3batu.ac.id/index.php/me \\
Vol.9, No.1, pp. 163-184, 2020 \\
\hline
\end{tabular}

\title{
Ancaman Ajaran Sesat di Lingkungan Kekristenan: Suatu Pelajaran Bagi Gereja-Gereja di Indonesia Morris Phillips Takaliuang ${ }^{a}$ \\ ${ }^{a}$ Institut Injil Indonesia, takaliuangmorris@gmail.com
}

\section{INFO ARTIKEL}

\section{Sejarah Artikel:}

Diterima : April 2020

Direvisi : April 2020

Disetujui: April 2020

Dipublikasi: April

2020

\section{Kata Kunci:}

Ajaran Sesat, Penyebab, Karakteristik, Solusi, Ortodoksi

Keywords: Heresy, Cause, Characteristics, Solution, Orthodoxy.

\begin{abstract}
ABSTRAK
Hadirnya ajaran sesat di lingkungan Kekristenan, sudah ada sejak eksisnya gereja di zaman para rasul. Pergerakan ajaran sesat tersebut, terus berlanjut sampai hari ini di seluruh dunia Kristen. Para rasul telah berjuang mengatasi dan menolak ajaran sesat tersebut. Tetapi gerakan ajaran tersebut, tetap berlangsung sampai hari ini. Bahaya, ancaman dan rongrongan ajaran sesat tadi sudah merusak, terus merusak dan menyelewengkan ajaran yang ortodoks, menyesatkan pikiran, merusak iman dan menimbulkan dekadensi moral Kristiani. Karena itulah gereja wajib, mensikapi dan menangkalnya. Tujuan dari penelitian dan penulisan artikel ini adalah: (1) Untuk memahami, menganalisis, mengkritisi dan menentukan sikap dan posisi yang jelas terhadap berbagai pengajaran sesat itu dan (2) untuk mengingatkan gereja supaya menyadari secara dini, ancaman dan bahaya dari ajaran sesat itu. Adapun metode penelitian yang digunakan dalam penulisan artikel ini adalah penggabungan antara "metode penelitian historis" dan "metode penelitian teologis", dengan prosedur sebagai berikut : (1) Menetapkan masalah untuk diteliti lebih lanjut, (2) Mencari dan menggali informasi tentang masalah tersebut secara komprehensif; menganalisis, mengkritisinya serta menentukan solusinya dan (3) Menyajikan hasil temuan secara deskriptif, informatif dan selektif. Hasil yang diperoleh dari penelitian yang sudah dilakukan adalah (1) Dalang pergerakan dan sumber ajaran sesat adalah roh setan sendiri yang adalah roh penyesat, (2) Inisiator, konseptor dan penganjur ajaran sesat, berasal dari internal gereja sendiri, melalui tokoh-tokohnya yang berpengaruh, (3) Ancaman dan serangan ajaran sesat sudah menghasilkan "gereja yang tersesat", yang telah menyeleweng dari kebenaran Kristus dan (4) Karena itu, seluruh gereja yang ada di bumi ini dan juga di Indonesia, diwajibkan untuk menangkal dan melawannya dengan ajaran yang ortodoksi
\end{abstract}

\section{ABSTRACT}

The presence of heresy in the Christian environment, has existed since the existence of the church in the apostolic era. The movement of the heresy, continues to this day throughout the Christian world. The apostles have struggled to overcome and reject the heresy. But the teaching movement, continues today. The dangers, threats and undermining of the heresies have corrupted, continued to corrupt and distort orthodox teachings, mislead the mind, damage the faith and cause Christian moral decadence. That's why the church is obliged to, address and counter it. The purpose of the research and writing of this article are: (1) To understand, analyze, criticize and determine clear attitudes and positions towards the various heresies and (2) to remind the church to realize early, threats and dangers of that heresy. The research method 
used in writing this article is a combination of "historical research methods" and "theological research methods", with the following procedures: (1) Define the problem for further research, (2) Finding and exploring information about the problem in a manner comprehensive; analyze, critique it and determine the solution and (3) Present findings descriptively, informative and selectively. The results obtained from research that have been done are (1) The mastermind behind the movement and source of heresy is the spirit of the devil himself who is a spirit of heresy, (2) Initiators, drafter and advocates of heresy, originating from the internal church itself, through influential figures, (3) Threats and attacks on heresies have resulted in 'lost churches', which have strayed from the truth of Christ and (4) Therefore, all churches on this earth and also in Indonesia, are required to ward off and fight them with teachings that are orthodoxy.

\section{PENDAHULUAN}

Hadir dan berkembangnya ajaran-ajaran sesat (bidatisme) dalam sejarah merupakan fakta yang tidak dapat disangkal. Kenyataan ini dapat dilihat sejak awal berdirinya gereja Tuhan dalam zaman perjanjian Baru. Para penulis Perjanjian Baru, benar-benar telah berjuang untuk menghadapi tantangan yang serius dari berbagai ajaran sesat. Rasul Yohanes, rasul Paulus dan rasul-rasul yang lain, dengan gigih telah berjuang untuk mempertahankan kemurnian ajaran gereja dari rongrongan ajaran-ajaran sesat tersebut. Mereka bahkan menunjukkan sikap yang amat tegas dan berani terhadap para penyesat tersebut, mulai dari mencela ajaran mereka sampai dengan mengutuk para penganutnya sebagai pengacau dan perusak doktrin yang ortodoks. Karena di balik dan di dalam ajaranajaran sesat tersebut ada aktivitas roh-roh penyesat yang berasal dari setan-setan, demikai tulis rasul Paulus dalam 1Timotius 4:1-2.

Lebih menarik lagi adalah bahwa setelah duapuluh satu abad gereja Tuhan ada dan berdiri di muka bumi ini, ternyata ajaran-ajaran sesat tersebut tetap hadir, bergerak dan menyesatkan banyak orang, terutama orang Kristen. Dan yang ganjil adalah ajaran dan praktek agama serta ibadah mereka menarik banyak orang dari berbagai kalangan dan latarberlakang budaya, zaman dan konteks. Karena itu, gereja tidak boleh tinggal diam dan merasa puas dengan dirinya sendiri. Sebab fakta adanya ajaran-ajaran sesat ini, merupakan reaksi dan usaha mereka untuk menjawab dan memenuhi kebutuhan manusia akan pegangan hidup dan ketenangan batin. Karena relasi dengan yang ilahi merupakan suatu tempat berlindung di masa yang penuh goncangan dan krisis kemanusiaan sepanjang sejarah.

Buku Megatrend 2000, menyajikan bangkitnya spiritualisme di seluruh dunia, suatu lahan yang sangat subur bagi lahir dan berkembangnya ajaran-ajaran sesat atau bidatbidat. Sebuah pengumpulan pendapat umum tahun 1987 mendapatkan 94 persen dari orang Amerika percaya akan Tuhan. India, Polandia dan Amerika Serikat mempunyai orangorang yang paling religius. Namun apakah orang Amerika religius atau spiritual? Bila mereka religius, mereka tidak termasuk satu agama atau gereja tertentu. Bukti dari sejumlah pengumpulan pendapat mengesankan bahwa istilah yang lebih tepat adalah spiritualisme.

Berikut adalah penjelasan lengkap tentang situasi tersebut di atas:

Hampir 70 persen dari penyebab boom bayi percaya akan Tuhan atau 'sesuatu kekuatan spiritual yang aktif dan positif'; setengahnya telah menjadi lebih spiritual dalam lima tahun terakhir, menurut center for the Vietnam Generation. Tiga perempat orang Amerika merasa terpuaskan secara spiritual, dan 61 persen mengatakan agama adalah 'sangat penting dalam hidup mereka'. Menurut pengumpulan pendapat USA Today 1987, Orang 
mengatakan, mereka berpaling kepada agama untuk mendapatkan kedamaian dan kesejahteraan. Namun ada bukti bahwa mereka tidak menemukan di dalam gereja. Sebuah pengumpulan pendapat umum tahun 1988 memperlihatkan 59 persen mengeluhkan bahwa Gereja atau Sinagoge mereka terlalu memperhatikan 'masalah organisasi ketimbang teologis atau spiritual'. Orang yang berpendidikan perguruan tinggi khususnya, kritis mengenai kurangnya pembinaan spiritual ini. Di Amerika utara, suatu jajaran agama baru diluar kerangka Kristen- yahudi mulai berakar. Walaupun pusat kelompok jalan utama Katolik, Protestan dan Yahudi telah menyusut, ratusan gereja buatan Amerika yang lebih kecil dan lebih terdesentralisasi baik Fundamentalis maupun alternative, telah berkembang. (Jhon Naisbitt \& patricia Aburdene; 2000).

Pertanyaannya sekarang, sudahkah gereja masa kini, sadar dan siuman bahwa situasi sosiologi agama di abad ini, sudah sedemikian rupa? Orang-orang pada umumnya sudah banyak yang kecewa terhadap gereja-gereja. Mereka lebih tertarik kepada spiritualisme baru, yang merupakan lahan yang sangat subur bagi berkembangnya ajaranajaran sesat/bidat-bidat. Apa strategi, antisipasi dan tindakan kita sebagai gereja dalam menghadapi realitas ini? Jawabannya adalah berusaha memahami dan menguasai strategi, ajaran dan praktik religiositas bidat-bidat tersebut secara utuh dan berusaha untuk menangkalnya dengan ajaran sehat dan benar dari Firman Allah (Ortodoksi).

\section{KAJIAN LITERATUR}

\section{Faktor-faktor Penyebab Munculnya Ajaran Sesat}

Penyebab munculnya ajaran sesat, menurut penulis adalah: (a) Pengaruh latar belakang Sistim hidup lama, (b) Pengaruh sinkretisme ajaran-ajaran agama dunia dengan filsafat sekuler dan Iman Kristen, (c) Ketidakpuasan dan kekecewaan orang Kristen terhadap praktik kerohanian gereja resmi yang sudah merosot, (d) Vitalitas rohani gereja semakin merosot dan rapuh akibat pengaruh Materialisme dan (e) Adanya intervensi dan pengaruh ajaran roh-roh setan.

\section{Pengaruh Latar Belakang Sistim Hidup Lama}

Ajaran sesat yang merupakan hasil pengaruh latar belakang sistim hidup lama, nampak di dalam ajaran Nomianisme. Bidat ini menganut paham bahwa jika seseorang ingin diselamatkan, khususnya orang kafir (non Yahudi), maka haruslah mereka disunat lalu masuk agama Yahudi (Yudaisme) dan menerima Hukum Tautat, dengan demikian mereka memperoleh keselamatan. (Paulus Daun; 2010). Para penganut bidat ini tidak menyangkal anugerah Tuhan tetapi berpendapat bahwa untuk diselamatkan, seseorang harus juga berpegang kepada melakukan perbuatan baik untuk memperoleh keselamatan. Jadi keselamatan dari Kristus merupakan hasil kerjasama antara usaha manusia dengan karya Allah (Sinergisme). Oleh karena masalah Nomianisme ini, gereja Rasuli, untuk kali yang pertama mengadakan konperensi di Yerusalem. Pada hasil akhir dari konperensi itu, rasul Petrus mengumumkan:

"Hai saudara-saudaraku, kamu tahu bahwa sejak semula Allah memilih aku diantara kamu, supaya dengan perantaraan mulutku bangsa-bangsa lain mendengar berita Injil dan menjadi percaya. Dan Allah mengenal hati manusia, telah menyatakan kehendak-Nya untuk menerima mereka, sebab Ia mengaruniakan Roh Kudus juga kepada mereka sama seperti kita, dan Ia sama sekali tidak mengadakan perbedaan antara kita dengan mereka, sesudah Ia menyucikan hati mereka oleh Iman. Kalau demikian mengapa kamu mau mencobai Allah dengan meletakkan pada tengkuk murid-murid itu suatu kuk, yang tidak dapat dipikul, baik oleh nenek moyang kita maupun oleh kita? Sebaliknya kita percaya, 
bahwa oleh kasih karunia Tuhan Yesus Kristus kita akan beroleh keselamatan sama seperti mereka juga. (Kisah Rasul 15:7-11).

Dari pernyataan di atas jelas bahwa theolog-theolog Kristen yang murni, seperti Paulus dan Petrus memperoleh kemenangan dalam mengatasi ajaran bidat Nomianisme dan dengan demikian gereja diselamatkan dari ajaran sesat ini. Juga dengan penegasan tersebut di atas, konperensi Yerusalem memutuskan bahwa Nomianisme ditolak dan bahwa keselamatan manusia hanya berdasarkan kasih karunia Allah melalui iman dari dan kepada Kristus. Walaupun demikian, bidat Nomianisme terus bergerak dan menyusup ke dalam gereja-gereja dengan tujuan merusak ajaran murni gereja. Salah satu tujuan rasul Paulus menulis surat kepada gereja Galatia adalah untuk melawan bidat ini; yang sedang meronggrong jemaat di sana. Paulus mengatakan:

"Kamu tahu, bahwa tidak seorangpun yang dibenarkan oleh karena melakukan hukum Taurat, tetapi hanya oleh karena iman dalam Kristus Yesus. Sebab itu kamipun telah percaya kepada Kristus Yesus, supaya kami dibenarkan oleh karena iman dalam Kristus dan bukan oleh karena melakukan hukum Taurat. Sebab tidak ada seorangpun yang dibenarkan oleh karena melakukan hukum Taurat." (Galatia 2:16)

\section{Pengaruh Sikritisme Ajaran Agama Dunia Dan Filsafat Sekuler Dengan Iman Kristen}

Sikretisme keKristenan dengan ajaran-ajaran agama kafir dan dengan filsafat Yunani, nampak dalam sistim bidat Manicheisme. Manicheisme merupakan agama dunia yang muncul antara keKristenan abad pertama dan Islam abad ketuju, yang dipengaruhi oleh aliran Gnostik dan merupakan campuran antara unsur-unsur Kristen dengan ajaran agama kafir (Persia) dan filsafat Yunani. (E.F. Harrison and Douglas; 1960). Bukti kongkrit tentang sinkritisme ini, nampak dalam ajaran Manicheisme tentang Universalisme. Dr. Dietrich Kuhl dalam bukunya menulis:

"Utusan-utusan Allah dengan tidak henti-hentinya membawa hikmat dari zaman ke zaman...pada suatu zaman, hal itu terjadi dengan kedatangan seorang utusan yaitu Budha dari India; pada suatu zaman yang lain hal itu terjadi melalui Zarathustra (dalam bentuk Yunani : Zoroaster) di Persia; pada zaman yang lain lagi hal itu terjadi melalui Yesus di negeri barat dan akhirnya pada masa kini wahyu dan kenabian ini menampakan diri dalam diri saya yaitu Mani, utusan Allah yang benar di negeri Babil .(Dietrich Kuhl; 2010).

Manicheisme didirikan oleh Manicheus yang hidup di Persia abad ke tiga (216276 M). Berdasarkan penglihatan, Manicheus menganggap dirinya Parakletos (Yohanes 16:7, Penghibur-Roh Kudus) yang dijanjikan Allah. Dia juga menyebut dirinya rasul Tuhan Yesus. Manicheus mengarang enam buku dan banyak suratnya yang terkumpul dalam kanon Manicheus. Pemerintah Persia menjadikan Manicheisme sebagai agama negara, hanya untuk waktu yang singkat. Pada abad ke tiga dan empat Manicheisme berkembang dengan cepat dan luas di Persia, Siria, Mesir, Afrika utara, Arabia dan juga di seluruh kekaisaran Romawi. (Dietrich Khul, 2010: 83). Pada abad ke tujuh, Manicheisme mencapai Turkistan (Rusia), Mongolia dan Tiongkok, tetapi akhirnya dilarang di sana. Bapa gereja Agustinus pernah menjadi penganut Manicheisme selama sembilan tahun, sebelum akhirnya bertobat dan menjadi pengikut Kristus. Manicheisme baru diketemukan kembali pada abad modern dan diantartanya ada yang tertulis dalam Bahasa Koptik (Mesir), Uigur (Mongolia), Tiongkok, Yunani dan Persia. (Dietrich Kuhl; 2010). Pada akhirnya Manicheisme mengalami penghambatan di mana-mana dan semakin menghilang pada abad pertengahan. Namun unsur-unsur Manicheisme berulangkali muncul 
dalam pelbagai bidat, misalnya bidat orang Bogomil di Bulgaria, Orang Katar atau Albigens di Perancis selatan pada abad pertengahan. (J.D Douglas; 1974).

\section{Ketidakpuasan Dan Kekecewaan Terhadap Praktik Kerohanian Gereja yang Sudah Merosot}

Banyak orang Kristen merasa kecewa, oleh karena kuasa Roh Kudus tidak menyatakan dirinya lagi dengan hebat dan ajaib di dalam gereja seperti dahulu. Hal nubuat, ekstase dan glossolalia sudah hilang lenyap. Kaum Kristen hanya mementingkan jabatan yang tetap dalam organisasi; disamping itu perkembangan jabatan gerejawi oleh sementara orang, dianggap terlalu membelenggu Roh yang bebas itu. Juga jemaat tidak lagi merindukan kedatangan mempelai laki-laki. Gereja sudah turun derajatnya dalam pandangan banyak anggotanya, karena tertipu oleh dunia. Timbul pertanyaan, dimanakah Roh, yang menyertai jemaat Tuhan selaku penolong dan penghibur seperti yang disebutkan oleh Yesus sendiri dalam Yohanes 14:16. (Dietrich Kuhl; 2010)

Oleh karena hal itulah, maka sekitar tahun 160 AD, di pedalaman Asia kecil, muncul suatu gerakan protes terhadap perkembangan tersebut diatas. Seorang tokoh bernama Montanus, menyatakan bahwa di dalam dirinya sudah datang roh penolong, yang terlah dijanjikan oleh Yesus (Yohanes 14:16,26). Montanus didampingi oleh dua orang nabiah, yakni Priscilla dan Maximilla. Montanus adalah pendiri Montanisme. Sebelum Montanus mendirikan bidatnya itu pada tahun $156 \mathrm{AD}$, ia adalah seorang imam agama Kybele (Cibele, Sibele) di Firgia (Asia kecil=Turki) yang mempraktekan pemujaan terhadap dewi Kybele, termasuk upacara-upacara kesuburan, percabulan agamawi, ekstase dan spiritisme. (A.G. Pringgodigdo and Hassan Shadily, 1976: 282). Tokoh-tokoh tersebut di atas sering berkata-kata dalam bahasa roh dan juga sering berekstase sampai pingsan. Mereka berkata, itulah tandanya roh penolong atau roh kudus telah datang dan berkata-kata melalui mulut mereka. Isi pernyataan mereka yang sering disampaikan dalam bahasa lidah atau bahasa roh (glosolalia) adalah:

"Akhir dunia sudah sampai, jangan kawin lagi, berpuasalah banyak dan tinggalkan dunia dan berkumpul di Pepuza (sebuah desa di Asia kecil), karena disana Tuhan akan mendirikan Yerusalem yang baru. Orang berbondong-bondong datang, semua menjual harta bendanya. Mereka rajin mencatat pernyataan-pernyataan dari pemimpin mereka dan itu mereka anggap sama harganya dengan Firman Perjanjian Lama dan Perjanjian Baru. Dan begitu besar kegairahan mereka, sehingga mereka tidak takut akan penghambatan; sebaliknya mereka melaporkan diri kepada yang berwajib" (H.Berkhof and Enklaar; 2010). Menurut nubuat Montanus, roh penolong itu menuntut kelakuan yang suci: seorang janda dilarang menikah untuk kedua kalinya. Jemaat disuruh menahan nafsu tubuh sebaikbaiknya, puasa harus dilakukan dengan aturan yang keras; mati syahid (martir) dipandang sebagai suatu keuntungan dan kehormatan, darahmu menjadi anak kunci Firdaus. (Tomas van den End, 1985: 49). Dalam buku sejarah gereja: Gereja mula-mula, Dr Dietrich Kuhl menulis tentang penyebab lahirnya bidat Montanisme ini:

"Timbulnya bidat-bidat ini merupakan suatu tantangan bagi gereja, untuk mengevaluasi diri sendiri, penghayatan iman dan keseimbangan pengajaran, karena mungkin sesekali ada factor-faktor kelalaian yang turut mengakibatkan berdirinya bidat itu. Hal itu juga berlaku untuk Montanisme: kebebasan dan spontanitas rohani serta imamat am orang-orang percaya mulai berkurang peranan dan pengaruhnya di dalam gereja yang am. Partisipasi aktif di dalam kebaktian beralih kepada partisipasi pasif. Karunia-karunia Roh kurang dipraktikan. Harapan eskatologi mulai menjadi pudar. Di dalam situsai inilah ajaran-ajaran Montanisme mempunyai daya Tarik yang sangat besar sehingga bapa Gereja Tertulianus pun ditarik masuk golongan Montanisme pada tahun 207.” (Dietrich Kuhl, 2010: 85) 
Vitalitas Rohani Gereja Semakin Merosot dan Rapuh Akibat Pengaruh Materialisme

Kenyataan merosot dan rapuhnya gereja-gereja di Amerika serikat pada abad ke 19 akibat materialisme diprensentasikan oleh Dr Jan Aritonang dalam bukunya, "Berbagai Aliran di dalam dan di sekitar Gereja":

"Sebenarnya vitalitas rohani Protestantisme Ortodoks sudah semakin rapuh. Standar kehidupan rohani, termasuk menyangkut penerimaan menjadi anggota gereja, semakin kendor. Kehidupan gereja lebih sering ditandai oleh hal-hal lahiriah: Gedung megah dan berbagai bentuk kemakmuran material lainnya. Karena itu tidak heran bila masa ituterutama parohan kedua abad itu-disebut "zaman sepuhan"(Gilded Age); di luar kelihatan mengkilap tetapi di dalam sudah keropos. Terutama di wilayah New England, yakni Kawasan Timur Laut Amerika Serikat sekarang, Calvinisme cukup kuat. Kendati ada sejumlah gerakan atau aliran yang menentangnya, misalnya Unitarianisme dan Transendentalisme, tetapi pengaruh paham itu sempat melemah, terutama setelah perang saudara 1860-1865. Aliran-aliran seperti ini baru menguat kembali menjelang akhir abad ke -19, sekaligus membuka jalan bagi pengaruh agama-agama dan mistisisme timur, yang nanti mewarnai Christian Science pada tahap lanjutan dari perkembangannya. (Jan $S$ Aritonang; 2010)

Dr Jan S Aritonang menjelaskan, Calvinisme yang dominan pada masa itu adalah Calvinisme dekaden (merosot), sama seperti Ortodoksi Protestan pada umumnya yang sudah sangat akrab berpadu dengan materialisme yang antara lain menumbuh kembangkan kapitalisme. Karena itu dimensi spiritual dari kenyataan sering diabaikan, dan ini menimbulkan kekosongan dan kehausan rohani pada banyak orang. Dalam keadaan seperti inilah Spiritualisme atau paham-paham yang dekat dengannya mendapat pasaran yang lumayan. Jadi dapat dikatakan bahwa Christian Science adalah suatu gerakan protes terhadap ortodoksi Protestan yang sudah terpengaruh materialisme modern. Hal itu dibenarkan juga oleh Stuart E Knee dalam bukunya, Christian Science in the age of Marry Bakker Eddy:

"Christian Science lahir dari suatu zaman Materialistis yang memandang manusia sebagai mesin...kalua ia sakit ia dipandang dan diperlakukan seperti mesin yang jalannya tidak beres. Ia lahir dari suatu zaman yang mencampur adukan dogma dengan iman, yang menolak untuk melihat hal-hal yang tak tampak dan kekal yang mengecam misticisme dan mengagungkan metode ilmiah." (Stuart E Knee; 2010). Merinci penjelasan sebelumnya J. Verkuyl dalam bukunya Gereja dan Bidat, memaparkan: "Tidak dapat disangkal bahwa Gerakan Christian Science ini adalah suatu reaksi terhadap faham materialisme. Tidak juga mengherankan bahwa timbulnya Gerakan ini adalah di Amerika serikat...dapat kita ketahui, uang, laba dan sukses memegang peranan yang sangat besar dalam kehidupan di Amerika...maka tidak mengherankan justru di negeri seperti Amerika, banyak orang yang terjerat jurang gerakan-gerakan spiritualis, yang menyangkal segala kuasa materi, dan yang berpendirian bahwa hanya Rohlah kenyataan satu-satunya, sebagai reaksi terhadap sikap hidup yang teramat materialistis itu. (J. Verkuyl; 2010)

\section{Intervensi Roh-Roh Setan}

Salah satu bagian dari kebenaran ajaran Alkitab yang sering diabaikan oleh banyak orang Kriten bahkan theolog adalah kebenaran tentang adanya hubungan antara setan ataupun roh jahat, dengan ajaran-ajaran sesat, yang merusak iman serta menyesatkan orang Kristen. Padahal perjanjian Baru sangat menegaskan hal tersebut. Lihatlah apa yang dikatakan oleh rasul Paulus dalam 1Timotius 4:1: "Tetapi roh dengan tegas mengatakan bahwa di waktu-waktu kemudian, akan ada orang yang akan murtad lalu mengikuti roh-roh penyesat dan ajaran setan-setan." Di dalam ayat ini setan dikaitkan dengan ajaran dan rohroh penyesat. Jadi jelas, setan mempunyai ajaran-ajaran atau doktrin-doktrin tertentu dan 
juga mempunyai tujuan, menyesatkan orang-orang Kristen. Dalam ayat itu juga dikatakan ada orang-orang yang murtad (meninggalkan iman) yaitu orang-orang Kristen yang terbujuk meninggalkan iman Alkitabiah yang benar, dan berpaling kepada suatu bentuk doktrin yang salah. (Derek Prince; 2010). Melanjutkan penjelasan tersebut di atas Stephen Tong menyatakan:

"Jika sesuatu hal terlihat berusaha untuk mengacaukan kebenaran, maka dibelakang gagasan itu pasti suara setan yang bekerja untuk mencapai tujuan yang tidak benar. Suara setan suara yang mengacaukan pengertian dan kebenaran, inilah yang selalu dikerjakan oleh setan-setan. (Stephen Tong; 2010).

Kalau kita memperhatikan sifat dan ciri ajaran-ajaran sesat, maka menjadi jelas bahwa kekeliruan, penyelewengan dan penyesatan yang mereka ajarkan, pastilah didalangi dan diinspirasi oleh setan dan roh-roh jahatnya. Kelicikan dan penipuan setan adalah sangat jelas, seperti diuraikan berikut ini:

"Jikalau setan memakai cara setan yang menakutkan, pasti saudara ketakutan. Setan yang demikian adalah setan yang bodoh, karena cara itu membuat manusia selalu lari dari setan dan tidak mau diganggu. Tetapi justru setan adalah setan, karena ia begitu licik, begitu pandai sampai ia memalsukan orang-orang baik, nabi yang baik, rasul-rasul yang bahkan memalsukan Kristus. Ia bertopeng seperti orang-orang suci. Alkitab mengatakan adanya nabi palsu, rasul palsu dan ada Kristus palsu. (Stephen Tong; 2010). Rasul Paulus juga mengingatkan jemaat di Korintus yang merupakan buah sulung pelayanannya, Ketika ia menulis: 'Tetapi aku takut, kalau-kalau kamu disesatkan dari kesetiaan kamu yang sejati kepada Kristus,' sama seperti Hawa diperdayakan oleh ular itu dengan kelicikannya (2 Korintus 11:3). Menghadapi semua kenyataan seperti itu, John Stott, menegaskan: "Apabila kedatangan Kristus yang pertama semata-mata bertujuan untuk menghapus dosa dan membinasakan segala perbuatan setan, maka orang Kristen tidak boleh berkompromi dengan setan, sebab kalau tidak demikian mereka akan berperang melawan Kristus". (John Stott; 1969). Dalam 2 Korintus 11:4, rasul Paulus memperingatkan tentang para pengajar sesat yang akan muncul: "sebab kamu sabar saja, jika ada seorang datang memberitakan Yesus yang lain daripada yang telah kami beritakan, atau memberitakan kepada kamu roh yang lain daripada yang telah kamu terima atau injil yang lain daripada yang telah kamu terima”. Peringatan di sini mencakup tiga hal: (a) Si penyesat mengajarkan atau memberitakan "Yesus yang lain", (b) mereka yang menerima berita yang menyesatkan ini menerima "roh yang lain" daripada yang telah mereka terima sebelumnya dan (c) mereka menerima "injil yang lain" daripada Injil yang benar. Orang-orang Korintus sebenarnya sudah menerima Roh Kudus; maka ketika Paulus berbicara tentang roh yang lain, di sini Paulus sedang berbicara perihal suatu roh yang tidak kudus, yakni setan yang menyesatkan, suatu roh penyesat.

Timbul pertanyaan, Apakah yang menyebabkan pintu terbuka sehingga setan dapat masuk ke dalam kehidupan gereja? Jawabannya adalah karena mereka menerima berita yang menyampaikan "Yesus yang lain'. Di sini letak inti permasalahannya. Begitu seseorang menaruh iman keada "Yesus yang lain", merekapun menerima 'roh yang lain'. Jadi cukup logis, jika kita bertanya, apakah di dalam gereja masa kini masih terdapat pengajar-pengajar sesat yang memberitakan yesus yang lain dengan ajaran-ajarannya yang bercorak Kristen atau Alkitabiah? Jawabannya jelas dan tegas yaitu ya!

Ada Yesus yang demikian terkenal di negara-negara Amerika selatan. Yesus ini digambarkan sebagia tokoh revolusioner beraliran Marxisme yang membela kaum papa dan siap melakukan revolusi bersenjata melawan kaum kapitalis. Yesus yang lain lagi, juga terkenal di lingkungan gerakan zaman baru. Ia digambarkan sebagai "guru" (pengajar rohani) dari negeri timur yang menggabungkan Injil dengan ajaran rahasia dari agama Hindu dan Budha. Tetapi Yesus yang Alkitabiah, yaitu pencipta segala sesuatu dan hakim 
semua manusia, tidak pernah ditampilkan dalam aliran ini. Kemudian ada Yesus yang memikat mereka yang condong kepada Humanisme. Yesus ini senatiasa berbicara tentang kasih dan pengampunan, tetapi sama sekali tidak pernah menyinggung tentang neraka maupun pertobatan. Yesus ini ditampilkan hanya sebagai juru selamat, tidak pernah sebagai hakim. Yesus ini juga tidak mengakui tentang perumpamaan seorang bangsawan yang kalimat terakhirnya berkata: "Akan tetapi semua seteruku ini, yang tidak suka Aku menjadi raja, bawahlah mereka kemari dan bunuhlah mereka di depan mataku (Lukas 19:27). Ada juga Yesus versi Sinterklas yang mengatakan kepada banyak orang bahwa yang perlu mereka lakukan hanyalah percaya dan mereka menerima apapun yang mereka minta, mulai dengan pekerjaan bergaji besar sampai mobil mewah dan rumah yang dilengkapi dengan kolam renang. Tetapi yesus ini seperti halnya yesus yang Humanisme, tidak pernah menyeruhkan pertobatan dan kekudusan. Celakanya, banyak orang Kristen dewasa ini terpikat untuk menerima salah satu dari Yesus palsu dan tidak Alkitabiah tersebut. Dengan menerima 'yesus yang lain' tersebut, mereka juga menerima "roh yang lain" yaitu 'roh-roh penyesat. (Derek Prince; 2000)

Oleh karena itu dapatlah disimpulkan bahwa setiap doktrin ataupun pemberitaan yang menyimpang dari kebenaran dan kekudusan Tuhan ataupun yang menyerang dan menggerogoti pribadi, sifat dan karya Kristus yang komprehensif ataupun yang merendahkan dan melecehkan otoritas Alkitab, semuanya berasal dari roh penyesat, yakni setan-setan. Derek Prince menegaskan:

"Sejak abad pertama Yesus menegaskan perlunya menasehati orang-orang di zamanNya untuk berjuang mempertahankan iman yang telah disampaikan kepada orang-orang kudus (Yudas 3). Perlunya perjuangan semacam ini semakin meningkat berkali lipat sejak zaman Yesus. Meskipun demikian, penyesatan setan itu tidak hanya berupa penyimpangan atau penyelewengan iman Kristen. Penyesatan itu meliputi semua agama, aliran kepercayaan atau falsafah yang menyingkirkan kebenaran-kebenaran utama dan mulia dalam Alkitab, khususnya segala sesuatu yang berhubungan dengan Yesus Kristus. Kita harus ingat bahwa setan selalu berusaha menyembunyikan atau menyelewengkan kedudukan Yesus yang sebenarnya. (Derek Prince; 2000). Maka menjadi semakin jelas, bahwa ajaran-ajaran sesat, pengaruhnya serta daya tariknya dan kesesatan yang terdapat di dalamnya, seperti yang disebutkan sebelumnya, umumnya harus dipahami juga sebagai serangan, godaan dan kuasa penyesatan yang berasal dari inspirasi dan konspirasi setan dan roh-roh jahatnya dengan para pengikutnya. Justru karena kesadaran ini, maka kita sebagai warga gereja harus melakukan segala sesuatu terhadap bahaya dan racun pengajaran sesat ini. Kita perlu melakukan apa yang dikatakan Tuhan dalam Alkitab:

"Akhirnya, hendaklah kamu kuat di dalam Tuhan di dalam kekuatan kuasa-Nya. Kenakanlah seluruh perlengkapan senjata Allah, supaya kamu dapat bertahan melawan tipu muslihat iblis; karena perjuangan kita bukanlah melawan darah dan daging, tetapi melawan pemerintah-pemerintah, melawan penguasa-penguasa, melawan penghulupenghulu dunia yang gelap ini, melawan roh-roh jahat di udara. Sebab itu ambillah seluruh perlengkapan senjata Allah, supaya kamu dapat mengadakan perlawanan pada hari yang jahat itu dan tetap berdiri, sesudah kamu menyelesaikan segala sesuatu. Jadi berdirilah tegap, berikatpinggangkan kebenaran dan berbajuzirahkan keadilan, kakimu berkasutkan kerelaan untuk memberitakan Injil damai sejahtera; dalam segala keadaan pergunakanlah perisai iman, sebab dengan perisai itu kamu akan dapat memadamkan semua panah api dari si jahat, dan terimalah ketopong keselamatan dan pedang Roh, yaitu firman Allah, dalam segala doa dan permohonan. Berdoalah setiap waktu di dalam Roh dan berjagajagalah di dalam doamu itu, dengan permohonan yang tidak putus-putusnya untuk segala orang kudus (Efesus 6:10-18). Karena itu tunduklah kepada Allah, dan lawanlah iblis, maka ia akan lari dari padamu (Yakobus 4:7). 


\section{METODE PENELITIAN}

Metode penelitian yang digunakan dalam penulisan artikel ini adalah penggabungan "metode penelitian historis" dan "metode penelitian teologis". Metode penelitian historis adalah suatu usaha dan cara pencarian secara sistematis tentang faktafakta yang mengandung magna yang berhubungan dengan pertanyaan tentang masa lampau dan penafsirannya. Dari sana orang-orang dapat belajar dari kekeliruan/kesalahan dan kebenaran-kebanaran dari fakta masa lalu dan pada saat yang sama, bersama dengan orang-orang yang berkepentingan, dapat terbantu untuk menetapkan pembaharuan masa kini dan sediki banyaknya dapat memperkirakan kecenderungan di masa depan (Andreas B. Subagio; 2004). Metode penelitian teologis, merupakan suatu refleksi, terutama berdasarkan data Alkitab, memformulasi dan mereformulasi data-data tersebut secara kritis dan menjadi norma bagi teologi itu sendiri, serta implikasinya bagi segenap kehidupan dengan cara yang selayak dan setepat mungkin dan dalam jangka Panjang bertujuan untuk memperbaharui gereja serta menjadikan kekristenan dapat dipercaya oleh pihak internal dan eksternal gereja (Andreas B. Subagio; 2004). Metode dan proses pengumpulan data dalam penulisan ini mengikuti langka-langka berikut : (1) merumuskan masalah dalam bentuk pertanyaan penelitian untuk diteliti, (2) Mencari dan menentukan sumber atau dokumen-dokumen yang membahas langsung tentang permasalahan yang dikaji, (3) Meringkas data-data dari sumber-sumber informasi tadi secara objektif, esensial dan kritis dan (4) Menyajikan hasil kajian terhadap informasi yang didapat, sesuai dengan maksud dan tujuan penelitian (Andreas B Subagio; 2004).

\section{HASIL DAN PEMBAHASAN}

\section{Faktor-Faktor Penyebab Munculnya Ajaran Sesat}

Penyebab munculnya ajaran sesat, menurut penulis adalah: (a) Pengaruh latar belakang Sistim hidup lama, (b) Pengaruh sinkretisme ajaran-ajaran agama dunia dengan filsafat sekuler dan Iman Kristen, (c) Ketidakpuasan dan kekecewaan orang Kristen terhadap praktik kerohanian gereja resmi yang sudah merosot, (d) Vitalitas rohani gereja semakin merosot dan rapuh akibat pengaruh Materialisme dan (e) Adanya intervensi dan pengaruh ajaran roh-roh setan.

\section{Pengaruh Latar Belakang Sistem Hidup Lama}

Ajaran sesat yang merupakan hasil pengaruh latar belakang sistim hidup lama, nampak di dalam ajaran Nomianisme. Bidat ini menganut paham bahwa jika seseorang ingin diselamatkan, khususnyua orang kafir (non Yahudi), maka haruslah mereka disunat lalu masuk agama Yahudi (Yudaisme) dan menerima Hukum Tautat, dengan demikian mereka memperoleh keselamatan. (Paulus Daun, 2010:39). Para penganut bidat ini tidak menyangkal anugerah Tuhan tetapi berpendapat bahwa untuk diselamatkan, seseorang harus juga berpegang kepada melakukan perbuatan baik untuk memperoleh keselamatan. Jadi keselamatan dari Kristus merupakan hasil kerjasama antara usaha manusia dengan karya Allah (Sinergisme). Oleh karena masalah Nomianisme ini, gereja Rasuli, untuk kali yang pertama mengadakan konperensi di Yerusalem. Pada hasil akhir dari konperensi itu, rasul Petrus mengumumkan: "Hai saudara-saudaraku, kamu tahu bahwa sejak semula Allah memilih aku diantara kamu, supaya dengan perantaraan mulutku bangsa-bangsa lain mendengar berita Injil dan menjadi percaya. Dan Allah mengenal hati manusia, telah menyatakan kehendak-Nya untuk menerima mereka, sebab Ia mengaruniakan Roh Kudus juga kepada mereka sama seperti kita, dan Ia sama sekali tidak mengadakan perbedaan antara kita dengan mereka, sesudah Ia menyucikan hati mereka oleh Iman. Kalau demikian mengapa kamu mau mencobai Allah dengan meletakkan pada tengkuk murid-murid itu suatu kuk, yang tidak dapat dipikul, baik oleh nenek moyang kita maupun oleh kita? 
Sebaliknya kita percaya, bahwa oleh kasih karunia Tuhan Yesus Kristus kita akan beroleh keselamatan sama seperti mereka juga. (Kisah Rasul 15:7-11).

Dari pernyataan di atas jelas bahwa teolog-teolog Kristen yang murni, seperti Paulus dan Petrus memperoleh kemenangan dalam mengatasi ajaran bidat Nomianisme dan dengan demikian gereja diselamatkan dari ajaran sesat ini. Juga dengan penegasan tersebut di atas, konperensi Yerusalem memutuskan bahwa Nomianisme ditolak dan bahwa keselamatan manusia hanya berdasarkan kasih karunia Allah melalui iman dari dan kepada Kristus. Walaupun demikian, bidat Nomianisme terus bergerak dan menyusup ke dalam gereja-gereja dengan tujuan merusak ajaran murni gereja. Salah satu tujuan rasul Paulus menulis surat kepada gereja Galatia adalah untuk melawan bidat ini; yang sedang meronggrong jemaat di sana. Paulus mengatakan: "Kamu tahu, bahwa tidak seorangpun yang dibenarkan oleh karena melakukan hukum Taurat, tetapi hanya oleh karena iman dalam Kristus Yesus. Sebab itu kamipun telah percaya kepada Kristus Yesus, supaya kami dibenarkan oleh karena iman dalam Kristus dan bukan oleh karena melakukan hukum Taurat. Sebab tidak ada seorangpun yang dibenarkan oleh karena melakukan hukum Taurat." (Galatia 2:16)

\section{Pengaruh Sikritisme Ajaran Agama Dunia Dan Filsafat Sekuler Dengan Iman Kristen}

Sikretisme kekristenan dengan ajaran-ajaran agama kafir dan dengan filsafat Yunani, nampak dalam sistim bidat Manicheisme. Manicheisme merupakan agama dunia yang muncul antara kekristenan abad pertama dan Islam abad ketujuh, yang dipengaruhi oleh aliran Gnostik dan merupakan campuran antara unsur-unsur Kristen dengan ajaran agama kafir (Persia) dan filsafat Yunani. (E.F. Harrison and Douglas; 1960). Bukti kongkrit tentang sinkritisme ini, nampak dalam ajaran Manicheisme tentang Universalisme. Dr. Dietrich Kuhl dalam bukunya menulis:

"Utusan-utusan Allah dengan tidak henti-hentinya membawa hikmat dari zaman ke zaman...pada suatu zaman, hal itu terjadi dengan kedatangan seorang utusan yaitu Budha dari India; pada suatu zaman yang lain hal itu terjadi melalui Zarathustra (dalam bentuk Yunani : Zoroaster) di Persia; pada zaman yang lain lagi hal itu terjadi melalui Yesus di negeri barat dan akhirnya pada masa kini wahyu dan kenabian ini menampakan diri dalam diri saya yaitu Mani, utusan Allah yang benar di negeri Babil (Dietrich Kuhl; 2010).

Manicheisme didirikan oleh Manicheus yang hidup di Persia abad ke tiga (216-276 M). Berdasarkan penglihatan, Manicheus menganggap dirinya Parakletos (Yohanes 16:7, Penghibur-Roh Kudus) yang dijanjikan Allah. Dia juga menyebut dirinya rasul Tuhan Yesus. Manicheus mengarang enam buku dan banyak suratnya yang terkumpul dalam kanon Manicheus. Pemerintah Persia menjadikan Manicheisme sebagai agama negara, hanya untuk waktu yang singkat. Pada abad ke tiga dan empat Manicheisme berkembang dengan cepat dan luas di Persia, Siria, Mesir, Afrika utara, Arabia dan juga di seluruh kekaisaran Romawi. (Dietrich Khul; 2010). Pada abad ke tujuh, Manicheisme mencapai Turkistan (Rusia), Mongolia dan Tiongkok, tetapi akhirnya dilarang di sana. Bapa gereja Agustinus pernah menjadi penganut Manicheisme selama sembilan tahun, sebelum akhirnya bertobat dan menjadi pengikut Kristus. Manicheisme baru diketemukan kembali pada abad modern dan diantartanya ada yang tertulis dalam Bahasa Koptik (Mesir), Uigur (Mongolia), Tiongkok, Yunani dan Persia. (Dietrich Kuhl; 2010). Pada akhirnya Manicheisme mengalami penghambatan di mana-mana dan semakin menghilang pada abad pertengahan. Namun unsur-unsur Manicheisme berulangkali muncul dalam pelbagai bidat, misalnya bidat orang Bogomil di Bulgaria, Orang Katar atau Albigens di Perancis selatan pada abad pertengahan. (J.D Douglas; 1974). 


\section{Ketidakpuasan dan Kekecewaan Terhadap Praktik Kerohanian Gereja yang Sudah Merosot}

Banyak orang Kristen merasa kecewa, oleh karena kuasa Roh Kudus tidak menyatakan dirinya lagi dengan hebat dan ajaib di dalam gereja seperti dahulu. Hal nubuat, ekstase dan glossolalia sudah hilang lenyap. Kaum Kristen hanya mementingkan jabatan yang tetap dalam organisasi; disamping itu perkembangan jabatan gerejawi oleh sementara orang, dianggap terlalu membelenggu Roh yang bebas itu. Juga jemaat tidak lagi merindukan kedatangan mempelai laki-laki. Gereja sudah turun derajatnya dalam pandangan banyak anggotanya, karena tertipu oleh dunia. Timbul pertanyaan, dimanakah Roh, yang menyertai jemaat Tuhan selaku penolong dan penghibur seperti yang disebutkan oleh Yesus sendiri dalam Yohanes 14:16. (Dietrich Kuhl; 2010).

Oleh karena hal itulah, maka sekitar tahun 160 AD, di pedalaman Asia kecil, muncul suatu gerakan protes terhadap perkembangan tersebut diatas. Seorang tokoh bernama Montanus, menyatakan bahwa di dalam dirinya sudah datang roh penolong, yang terlah dijanjikan oleh Yesus (Yohanes 14:16,26). Montanus didampingi oleh dua orang nabiah, yakni Priscilla dan Maximilla. Montanus adalah pendiri Montanisme. Sebelum Montanus mendirikan bidatnya itu pada tahun 156 AD, ia adalah seorang imam agama Kybele (Cibele, Sibele) di Firgia (Asia kecil=Turki) yang mempraktekan pemujaan terhadap dewi Kybele, termasuk upacara-upacara kesuburan, percabulan agamawi, ekstase dan spiritisme. (A.G. Pringgodigdo and Hassan Shadily, 1976: 282). Tokoh-tokoh tersebut diatas sering berkata-kata dalam bahasa roh dan juga sering berekstase sampai pingsan. Mereka berkata, itulah tandanya roh penolong atau roh kudus telah datang dan berkata-kata melalui mulut mereka. Isi pernyataan mereka yang sering disampaikan dalam bahasa lidah atau bahasa roh (glosolalia) adalah "Akhir dunia sudah sampai, jangan kawin lagi, berpuasalah banyak dan tinggalkan dunia dan berkumpul di Pepuza (sebuah desa di Asia kecil), karena disana Tuhan akan mendirikan Yerusalem yang baru. Orang berbondongbondong datang, semua menjual harta bendanya. Mereka rajin mencatat pernyataanpernyataan dari pemimpin mereka dan itu mereka anggap sama harganya dengan Firman Perjanjian Lama dan Perjanjian Baru. Dan begitu besar kegairahan mereka, sehingga mereka tidak takut akan penghambatan; sebaliknya mereka melaporkan diri kepada yang berwajib". (H. Berkhof and Enklaar; 2010).

Menurut nubuat Montanus, roh penolong itu menuntut kelakuan yang suci: seorang janda dilarang menikah untuk kedua kalinya. Jemaat disuruh menahan nafsu tubuh sebaikbaiknya, puasa harus dilakukan dengan aturan yang keras; mati syahid (martir) dipandang sebagai suatu keuntungan dan kehormatan, darahmu menjadi anak kunci Firdaus. (Tomas van den End; 1985). Dalam buku sejarah gereja: Gereja mula-mula, Dr Dietrich Kuhl menulis tentang penyebab lahirnya bidat Montanisme ini "Timbulnya bidat-bidat ini merupakan suatu tantangan bagi gereja, untuk mengevaluasi diri sendiri, penghayatan iman dan keseimbangan pengajaran, karena mungkin sesekali ada factor-faktor kelalaian yang turut mengakibatkan berdirinya bidat itu. Hal itu juga berlaku untuk Montanisme: kebebasan dan spontanitas rohani serta imamat am orang-orang percaya mulai berkurang peranan dan pengaruhnya di dalam gereja yang am. Partisipasi aktif di dalam kebaktian beralih kepada partisipasi pasif. Karunia-karunia Roh kurang dipraktikan. Harapan eskatologi mulai menjadi pudar. Di dalam situsai inilah ajaran-ajaran Montanisme mempunyai daya Tarik yang sangat besar sehingga bapa Gereja Tertulianus pun ditarik masuk golongan Montanisme pada tahun 207.” (Dietrich Kuhl; 2010) 


\section{Vitalitas Rohani Gereja Semakin Merosot Dan Rapuh Akibat Pengaruh Materialisme}

Kenyataan merosot dan rapuhnya gereja-gereja di Amerika serikat pada abad ke 19 akibat materialisme diprensentasikan oleh Dr Jan Aritonang dalam bukunya, "Berbagai Aliran di dalam dan di sekitar Gereja"

"Sebenarnya vitalitas rohani Protestantisme Ortodoks sudah semakin rapuh. Standar kehidupan rohani, termasuk menyangkut penerimaan menjadi anggota gereja, semakin kendor. Kehidupan gereja lebih sering ditandai oleh hal-hal lahiriah: Gedung megah dan berbagai bentuk kemakmuran material lainnya. Karena itu tidak heran bila masa itu-terutama parohan kedua abad itu-disebut 'zaman sepuhan' (Gilded Age); di luar kelihatan mengkilap tetapi di dalam sudah keropos. Terutama di wilayah new England, yakni Kawasan timur laut Amerika Serikat sekarang, Calvinisme cukup kuat. Kendati ada sejumlah gerakan atau aliran yang menentangnya, misalnya Unitarianisme dan Transendentalisme, tetapi pengaruh paham itu sempat melemah, terutama setelah perang saudara 1860-1865. Aliran-aliran seperti ini baru menguat kembali menjelang akhir abad ke -19, sekaligus membuka jalan bagi pengaruh agama-agama dan mistisisme timur, yang nanti mewarnai Christian Science pada tahap lanjutan dari perkembangannya. (Jan $S$ Aritonang; 2010).

Jan S Aritonang menjelaskan, Calvinisme yang dominan pada masa itu adalah Calvinisme dekaden (merosot), sama seperti Ortodoksi Protestan pada umumnya yang sudah sangat akrab berpadu dengan materialisme yang antara lain menumbuh kembangkan kapitalisme. Karena itu dimensi spiritual dari kenyataan sering diabaikan, dan ini menimbulkan kekosongan dan kehausan rohani pada banyak orang. Dalam keadaan seperti inilah Spiritualisme atau paham-paham yang dekat dengannya mendapat pasaran yang lumayan. Jadi dapat dikatakan bahwa Christian Science adalah suatu gerakan protes terhadap ortodoksi Protestan yang sudah terpengaruh materialisme modern. Hal itu dibenarkan juga oleh Stuart E Knee dalam bukunya, Christian Science in the age of Marry Bakker Eddy.

"Christian Science lahir dari suatu zaman Materialistis yang memandang manusia sebagai mesin...kalua ia sakit ia dipandang dan diperlakukan seperti mesin yang jalannya tidak beres. Ia lahir dari suatu zaman yang mencampur adukan dogma dengan iman, yang menolak untuk melihat hal-hal yang tak tampak dan kekal...yang mengecam misticisme dan mengagungkan metode ilmiah.” (Stuart E Knee; 2010). Merinci penjelasan sebelumnya J. Verkuyl dalam bukunya Gereja dan Bidat, memaparkan: "Tidak dapat disangkal bahwa Gerakan Christian Science ini adalah suatu reaksi terhadap faham materialisme. Tidak juga mengherankan bahwa timbulnya Gerakan ini adalah di Amerika serikat...dapat kita ketahui, uang, laba dan sukses memegang peranan yang sangat besar dalam kehidupan di Amerika...maka tidak mengherankan justru di negeri seperti Amerika, banyak orang yang terjerat jurang gerakan-gerakan spiritualis, yang menyangkal segala kuasa materi, dan yang berpendirian bahwa hanya Rohlah kenyataan satu-satunya, sebagai reaksi terhadap sikap hidup yang teramat materialistis itu. (J. Verkuyl; 2010).

\section{Adanya Intervensi Roh-Roh Setan}

Salah satu bagian dari kebenaran ajaran Alkitab yang sering diabaikan oleh banyak orang Kriten bahkan teolog adalah kebenaran tentang adanya hubungan antara setan ataupun roh jahat, dengan ajaran-ajaran sesat, yang merusak iman serta menyesatkan orang Kristen. Padahal perjanjian Baru sangat menegaskan hal tersebut. Lihatlah apa yang dikatakan oleh rasul Paulus dalam 1 Timotius 4:1: "Tetapi roh dengan tegas mengatakan bahwa di waktu-waktu kemudian, akan ada orang yang akan murtad lalu mengikuti roh-roh penyesat dan ajaran setan-setan." Di dalam ayat ini setan dikaitkan dengan ajaran dan roh- 
roh penyesat. Jadi jelas, setan mempunyai ajaran-ajaran atau doktrin-doktrin tertentu dan juga mempunyai tujuan, menyesatkan orang-orang Kristen. Dalam ayat itu juga dikatakan ada orang-orang yang murtad (meninggalkan iman) yaitu orang-orang Kristen yang terbujuk meninggalkan iman Alkitabiah yang benar, dan berpaling kepada suatu bentuk doktrin yang salah. (Derek Prince; 2010). Melanjutkan penjelasan tersebut di atas Stephen Tong menyatakan "Jika sesuatu hal terlihat berusaha untuk mengacaukan kebenaran, maka dibelakang gagasan itu pasti suara setan yang bekerja untuk mencapai tujuan yang tidak benar. Suara setan suara yang mengacaukan pengertian dan kebenaran, inilah yang selalu dikerjakan oleh setan-setan (Stephen Tong; 2010).

Kalau kita memperhatikan sifat dan ciri ajaran-ajaran sesat, maka menjadi jelas bahwa kekeliruan, penyelewengan dan penyesatan yang mereka ajarkan, pastilah didalangi dan diinspirasi oleh setan dan roh-roh jahatnya. Kelicikan dan penipuan setan adalah sangat jelas, seperti diuraikan berikut ini:

Jikalau setan memakai cara setan yang menakutkan, pasti saudara ketakutan.

Setan yang demikian adalah setan yang bodoh, karena cara itu membuat manusia selalu lari dari setan dan tidak mau diganggu. Tetapi justru setan adalah setan, karena ia begitu licik, begitu pandai sampai ia memalsukan orang-orang baik, nabi yang baik, rasul-rasul yang bahkan memalsukan Kristus. Ia bertopeng seperti orang-orang suci. Alkitab mengatakan adanya nabi palsu, rasul palsu dan ada Kristus palsu. (Stephen Tong; 2010)

Rasul Paulus juga mengingatkan jemaat di Korintus yang merupakan buah sulung pelayanannya, Ketika ia menulis: 'Tetapi aku takut, kalau-kalau kamu disesatkan dari kesetiaan kamu yang sejati kepada Kristus,' sama seperti Hawa diperdayakan oleh ular itu dengan kelicikannya (2 Korintus 11:3). Menghadapi semua kenyataan seperti itu, John Stott, menegaskan: "Apabila kedatangan Kristus yang pertama semata-mata bertujuan untuk menghapus dosa dan membinasakan segala perbuatan setan, maka orang Kristen tidak boleh berkompromi dengan setan, sebab kalau tidak demikian mereka akan berperang melawan Kristus" (John Stott; 1969). Dalam 2 Korintus 11:4, rasul Paulus memperingatkan tentang para pengajar sesat yang akan muncul: "sebab kamu sabar saja, jika ada seorang datang memberitakan Yesus yang lain daripada yang telah kami beritakan, atau memberitakan kepada kamu roh yang lain daripada yang telah kamu terima atau injil yang lain daripada yang telah kamu terima". Peringatan di sini mencakup tiga hal: (a) Si penyesat mengajarkan atau memberitakan "Yesus yang lain", (b) mereka yang menerima berita yang menyesatkan ini menerima "roh yang lain" daripada yang telah mereka terima sebelumnya dan (c) mereka menerima "injil yang lain" daripada Injil yang benar. Orangorang Korintus sebenarnya sudah menerima Roh Kudus; maka ketika Paulus berbicara tentang roh yang lain, di sini Paulus sedang berbicara perihal suatu roh yang tidak kudus, yakni setan yang menyesatkan, suatu roh penyesat.

Timbul pertanyaan, Apakah yang menyebabkan pintu terbuka sehingga setan dapat masuk ke dalam kehidupan gereja? Jawabannya adalah karena mereka menerima berita yang menyampaikan "Yesus yang lain'. Di sini letak inti permasalahannya. Begitu seseorang menaruh iman kepada "yesus yang lain", mereka pun menerima "roh yang lain". Jadi cukup logis, jika kita bertanya, apakah di dalam gereja masa kini masih terdapat pengajar-pengajar sesat yang memberitakan yesus yang lain dengan ajaran-ajarannya yang bercorak Kristen atau Alkitabiah? Jawabannya jelas dan tegas yaitu ya!

Ada Yesus yang demikian terkenal di negara-negara Amerika selatan. Yesus ini digambarkan sebagia tokoh revolusioner beraliran Marxisme yang membela kaum papa dan siap melakukan revolusi bersenjata melawan kaum kapitalis. Yesus yang lain lagi, juga terkenal di lingkungan gerakan zaman baru. Ia digambarkan sebagai "guru" (pengajar rohani) dari negeri timur yang menggabungkan Injil dengan ajaran rahasia dari agama 
Hindu dan Budha. Tetapi Yesus yang Alkitabiah, yaitu pencipta segala sesuatu dan hakim semua manusia, tidak pernah ditampilkan dalam aliran ini. Kemudian ada Yesus yang memikat mereka yang condong kepada Humanisme. Yesus ini senatiasa berbicara tentang kasih dan pengampunan, tetapi sama sekali tidak pernah menyinggung tentang neraka maupun pertobatan. Yesus ini ditampilkan hanya sebagai juru selamat, tidak pernah sebagai hakim. Yesus ini juga tidak mengakui tentang perumpamaan seorang bangsawan yang kalimat terakhirnya berkata: "Akan tetapi semua seteruku ini, yang tidak suka Aku menjadi raja, bawahlah mereka kemari dan bunuhlah mereka di depan mataku (Lukas 19:27). Ada juga Yesus versi Sinterklas yang mengatakan kepada banyak orang bahwa yang perlu mereka lakukan hanyalah percaya dan mereka menerima apapun yang mereka minta, mulai dengan pekerjaan bergaji besar sampai mobil mewah dan rumah yang dilengkapi dengan kolam renang. Tetapi yesus ini seperti halnya yesus yang Humanisme, tidak pernah menyeruhkan pertobatan dan kekudusan. Celakanya, banyak orang Kristen dewasa ini terpikat untuk menerima salah satu dari Yesus palsu dan tidak Alkitabiah tersebut. Dengan menerima "yesus yang lain" tersebut, mereka juga menerima "roh yang lain' yaitu 'roh-roh penyesat'. (Derek Prince; 2000).

Oleh karena itu dapatlah disimpulkan bahwa setiap doktrin ataupun pemberitaan yang menyimpang dari kebenaran dan kekudusan Tuhan ataupun yang menyerang dan menggerogoti pribadi, sifat dan karya Kristus yang komprehensif ataupun yang merendahkan dan melecehkan otoritas Alkitab, semuanya berasal dari roh penyesat, yakni setan-setan. Derek Prince menegaskan "Sejak abad pertama Yesus menegaskan perlunya menasehati orang-orang di zaman-Nya untuk berjuang mempertahankan iman yang telah disampaikan kepada orang-orang kudus (Yudas 3). Perlunya perjuangan semacam ini semakin meningkat berkali lipat sejak zaman Yesus. Meskipun demikian, penyesatan setan itu tidak hanya berupa penyimpangan atau penyelewengan iman Kristen. Penyesatan itu meliputi semua agama, aliran kepercayaan atau falsafah yang menyingkirkan kebenarankebenaran utama dan mulia dalam Alkitab, khususnya segala sesuatu yang berhubungan dengan Yesus Kristus. Kita harus ingat bahwa setan selalu berusaha menyembunyikan atau menyelewengkan kedudukan Yesus yang sebenarnya (Derek Prince; 2000).

Maka menjadi semakin jelas, bahwa ajaran-ajaran sesat, pengaruhnya serta daya tariknya dan kesesatan yang terdapat di dalamnya, seperti yang disebutkan sebelumnya, umumnya harus dipahami juga sebagai serangan, godaan dan kuasa penyesatan yang berasal dari inspirasi dan konspirasi setan dan roh-roh jahatnya dengan para pengikutnya. Justru karena kesadaran ini, maka kita sebagai warga gereja harus melakukan segala sesuatu terhadap bahaya dan racun pengajaran sesat ini. Kita perlu melakukan apa yang dikatakan Tuhan dalam Alkitab "Akhirnya, hendaklah kamu kuat di dalam Tuhan di dalam kekuatan kuasa-Nya. Kenakanlah seluruh perlengkapan senjata Allah, supaya kamu dapat bertahan melawan tipu muslihat iblis; karena perjuangan kita bukanlah melawan darah dan daging, tetapi melawan pemerintah-pemerintah, melawan penguasa-penguasa, melawan penghulu-penghulu dunia yang gelap ini, melawan roh-roh jahat di udara. Sebab itu ambillah seluruh perlengkapan senjata Allah, supaya kamu dapat mengadakan perlawanan pada hari yang jahat itu dan tetap berdiri, sesudah kamu menyelesaikan segala sesuatu. Jadi berdirilah tegap, berikatpinggangkan kebenaran dan berbajuzirahkan keadilan, kakimu berkasutkan kerelaan untuk memberitakan Injil damai sejahtera; dalam segala keadaan pergunakanlah perisai iman, sebab dengan perisai itu kamu akan dapat memadamkan semua panah api dari si jahat, dan terimalah ketopong keselamatan dan pedang Roh, yaitu firman Allah, dalam segala doa dan permohonan. Berdoalah setiap waktu di dalam Roh dan berjaga-jagalah di dalam doamu itu, dengan permohonan yang tidak putus-putusnya untuk segala orang kudus (Efesus 6:10-18). Karena itu tunduklah kepada Allah, dan lawanlah iblis, maka ia akan lari dari padamu (Yakobus 4:7) 


\section{Karakteristik Ajaran -Ajaran Sesat Dan Sanggahan Terhadapnya}

Karakteristik atau ciri-ciri ajaran sesat, nampak jelas dalam pandangan mereka tentang (a) Doktrin AllahTritunggal yang menyesatkan (b) Doktrin Kristologi yang menyimpang dan menyeleweng dan (c) Adanya spirit dan sifat Satanisme

\section{Doktrin Allah Tritunggal yang Menyesatkan}

Ajaran-ajaran sesat dalam gereja mula-mula yang berkaitan dengan ketritunggalan Allah yang Alkitabiah, jatuh dalam dua ekstrim yakni Unitarianisme dan Triteisme. Unitarianisme menerima keberadaan satu Allah, tetapi menyangkali, mengabaikan dan menafsirkan salah ketiga-Nya. Contohnya pertama adalah Arianisme ( didirikan oleh Arian yang adalah seorang sesat yang hidup pada masa gereja mula-mula),mengajarkan bahwa keAllahan terdiri dari satu pribadi yang kekal, yang pada awalnya, menciptakan sebuah makhluk malaekat super menurut gambar-nya sendiri, anak tunggal-Nya, yang oleh-Nya Dia menjadikan dunia, dan bahwa Roh Kudus adalah makhluk pertama dan terbesar yang diciptakan oleh Anak. Pengajaran sesat Arianisme ini menyatakan bahwa Allah adalah satu Allah secara matematis dan bahwa Anak dan Roh Kudus adalah makhluk ciptaan. Contoh kedua adalah Sabellianisme (didirikan oleh uskup Sabellius, seorang sesat dari gereja mula-mula) mengajarkan bahwa Bapa, Anak dan Roh Kudus, hanyalah tiga aspek atau tiga manifestasi dari angka yang mutlak satu Allah. Berikut argumentasi dan ilustrasi yang dikemukakannya. Sebagaimana seseorang, bisa menjadi seorang anak, lalu seorang suami dan berikutnya seorang ayah, tetapi orang tersebut adalah orang yang sama, begitu juga dengan Allah sebagai Bapa, Anak dan Roh Kudus. Ajaran ini bertentangan dengan Alkitab yang memberikan perbedaan jelas antara Bapa, Anak dan Roh Kudus. Bapa mengasihi dan mengutus Anak. Anak pergi dan kemudian Kembali kepada Bapa. Anak berdoa dan menjadi perantara kepada Bapa. Bapa dan Anak mengutus Roh Kudus. Roh Kudus menjadi perantara kepada bapa dan Anak. Selanjutnya Triteisme, mengajarkan dan menerima ketigaan Allah tetapi menolak keesaan-Nya. Ajaran ini tidak seimbang dalam wahyu tentang Allah sebagai Bapa, Anak dan Roh Kudus. Aliran pemikiran ini, menyangkal kesatuan pribadi-pribadi dalam keAllahan dan mengajarkan bahwa Bapa, Anak dan Roh Kudus adalah tiga makhluk yang terpisah dan menyatakan ada tiga Allah. Jadi bagi Triteisme, Bapa, Anak dan Roh Kudus adalah tiga Allah yang berbeda. (Kevin J. Corner, 2004). Dr. Dale merumuskan tentang Allah Tritunggal yang Alkitabiah:

"Dari kekekalan sampai kekekalan, Allah adalah Bapa, Anak dan Roh Kudus. Roh Kudus adalah Allah namun terpisah dari Bapa dan Anak. Hanya ada satu Allah namun dalam kekekalan ada tiga pribadi. Tidak ada tiga Allah, tetapi dalam kehidupan dan keberadaan satu Allah, ada tiga pusat kesadaran, kehendak dan perbuatan dan semuanya kita kenali sebagai BAPA, ANAK DAN ROH KUDUS. Bapa adalah segala kepenuhan keAllahan, tidak dapat dilihat, tanpa bentuk, yang tidak pernah dan tidak bisa dilahat oleh manusia. Anak adalah segala kepenuhan keAllahan, berwujud dan bisa dilihat. Roh Kudus adalah segala kepenuhan keAllahan yang bertindak dengan cepat atas ciptaan, sehingga memanifestasikan atau menyingkapkan Bapa dan Anak. Bapa merencanakan penebusan, Anak menjalankan penebusan, Roh Kudus mererapkan penebusan”. (Kevin J. Conner; 2004).

\section{Doktrin Kristologia Yang Menyimpang Dan Menyeleweng}

Sebenarnya tidak ada ajaran sesat yang baru pada saat ini, karena semuanya merupakan kebangkitan dari ajaran-ajaran lama yang sudah muncul dalam Injil dan surat dari para penulis apostolik. Oleh karena muncul dan berkembangnya ajaran penyesatan ini, maka berbagai dewan dari bapa-bapa gereja, berkumpul bersama untuk membuat pernyataan iman dan doktrin untuk membela Kristologi yang Alkitabiah. Berikut beberapa 
ajaran sesat yang utama tentang pribadi dan karya Kristus, yang menjadi dasar bagi ajaran sesat berikutnya dalam sejarah keKristenan: Pertama, Kristologi Ebionit, kedua, Kristologi Gnostik, Ketiga, Kristologi Arianisme, Keempat, Kristologi Apolonarianisme, Kelima, Kristologi Nestorianisme, Keenam, Kristologi Euthisianisme, Ketujuh, Kristologi Monofisitisme, Kedelapan, Kristologi hasil skeptisisme abad pencerahan, Kesembilan Kristologi, Jumat Agung tanpa Paskah dan Kesepuluh, Kristologi Sosial-politik.

Paripurna. Terdapat tiga aliran dalam gnostik, (1) Dosete yang menyangkal kenyataan tubuh Kristus dan menyatakan bahwa tubuh Kristus hanyalah penampakan roh, (2) Gnostik yang mengajarkan bahwa Kristus memiliki tubuh yang nyata tetapi menyangkal kenyataan bahwa tubuh itu bersifa fisik atau materi. Mereka yakin bahwa karena daging mewarisi sifat jahat, maka tubuh Kristus tidak mungkin tubuh daging, dan (3) Seritian, yakni gnostik yang memakai nama Cerinthius, yang mengajarkan bahwa Yesus dan Kristus berbeda; bahwa Yesus adalah manusia biasa, anak Yusuf dan Maria, dan bahwa Kristus adalah roh dan kuasa Allah yang turun atas Yesus pada saat Dia dibaptis di sungai Yordan. Mereka mengajarkan bahwa Kristus meninggalkan Yesus saat Dia disalib, yang meninggalkan-Nya untuk menderita dan mati sendirian. Ajaran-ajaran sesat Gnostik tersebut diatas disinggung dan dibicarakan dalam surat Kolose, 1 Timotius, 2Timotius, 1Yohanes, Yudas dan Wahyu (Yohanes 20:31; 1Yohanes 5:20; 1Yohanes 2:1; Ibrani 2:14; 1Yohanes 4:1-4; 1Timotius 3:16; Kolose 1;19; 2:9).

Arianisme, merupakan ajaran Arius, seorang iman dari Aleksandria Mesir. Arius mengajarkan bahwa Kristus tidak ada sebelumnya. Dia adalah makhluk ciptaan dan bahwa oleh-Nya semua benda lain diciptakan. Dalam keadaan-Nya yang diciptakan, Dia disebut logos, Anak, Anak tunggal dan awal ciptaan Allah (Yohanes 1:1-3, 14-18; Wahyu 3:14). Arius mengajarkan bahwa meski Anak disebut Allah, Dia bukanlah Allah dalam pengertian yang sepenuhnya dari kata tersebut, tetapi merupakan yang tertinggi dari seluruh makhluk ciptaan. Dia seperti Allah, tetapi bukan Allah, separuh Allah antara manusia dan Allah. Arianisme dikutuk selama tahun 321-325 M oleh uskup Alexander dan Arius dipecat dari gereja manapun pada saat itu. Ajaran ini menyangkal kekekalan dan kesetaraan pribadi Kristus dengan Bapa dan Roh Kudus, dan menjadikan Kristus makhluk ciptaan belaka.

Aliran Apolonarianisme, didirikan oleh Apolinaris, seorang Uskup terkemuka dari Laodekia. Dalam pengajarannya, ia menyatakan bahwa Kristus memiliki tubuh yang sesungguhnya dan jiwa binatang, tetapi tidak memiliki roh atau pikiran yang rasional. Menyangkut kesatuan dari dua hakekat dalam satu pribadi Kristus, dia mengajarkan bahwa Anak yang kekal mendukung roh dan pikiran Kristus Yesus. Tubuh dan jiwa adalah bagian dari kemanusiaan dan Anak yang kekal adalah adalah bagian dari keilahian atau roh Yesus. Pengajaran ini, menolak dan menyangkal keutuhan hakikat kemanusiaan Yesus dan mengajarkan bahwa Kristus hanyalah dua bagian dan bukannya kemanusiaan dari roh, jiwa dan tubuh yang penuh dan lengkap (Tesalonika 5:23). Oleh konsili atau dewan gereja di Konstantinopel tahun 381 M, Ajaran Apolonarianisme di kutuk sebagai ajaran sesat atau bidat.

Aliran pemikiran Nestorianisme, didirikan oleh uskup Nestorius, menyatakan bahwa dalam pribadi Kristus, ada kepribadian ganda, namun dia menyangkal kesatuan nyata dari hakekat ilahi dan manusiawi di dalam Kristus, dengan menyatakan bahwa logos (kepribadian ilahi) berdiam di dalam Kristus Yesus (kepribadian manusiawi). Dia menghadirkan Kristus sebagai manusia yang dipenuhi Roh, dipenuhi dengan Allah, tetapi tanpa keilahian dan kemanusiaan yang sejati di dalam satu pribadi. Pengajaran Nestorianisme ini, ditentang oleh Uskup Cyril dari Aleksandria dan Nestorius dikutuk dan ajarannya dilarang beredar oleh konsili atau sidang sinode gereja di Efesus tahun $431 \mathrm{M}$. Ajaran ini, mirip dengan pandangan ektrim dari Kenotisisme, yang menyatakan bahwa 
Ketika Kristus menjadi manusia, Dia mengosongkan Diri-Nya dari sifat-sifat ilahi yang ada pada-Nya, sehingga sebagai manusia, Dia membuat kesalahan-kesalahan intelektual.

Aliran pemikiran Euthisianisme, didirikan oleh Eutyches, menyatakan pengajaran yang berlawanan dengan Nestorianisme. Euthyces memandang bahwa Kristus hanya memiliki satu hakekat dan kehendak, bukan dua hakekat atau kehendak yang terpisah. Bagi dia, hakekat ilahi dan manusia Kristus Yesus begitu tercampur menjadi satu sehingga, menbentuk hakekat ketiga. Ajaran ini menjadikan Kristus bukan sebagai Allah dan juga bukan sebagai manusia, tetapi sebagai pribadi ketiga, hasil percampuran dua hakekat yang ada pada Yesus Kristus. Bagi Eutyches, segala sesuatu tentang Kristus adalah bersifat ilahi, baik tubuh maupun hakekat kemanusiaaNya.

Monofisitisme, merupakan cabang dari Euthisianisme yang mengajarkan bahwa Kristus hanya memiliki satu hakekat, satu kehendak. Sidang Sinode/konsisli di Konstantinopel adalah tahun 680-681, mengutuk doktrin ini, dan menyatakan bahwa Kristus memiliki dua hakekat yang berbeda, ilahi dan manusiawi dan memiliki dua akal budi dan dua kehendak. Keduanya berada dalam kesatuan yang harmonis, di mana kehendak manusiawi tunduk pada kehendak ilahi. Aliran lain yang menjadi bagian dari Monofisitisme, yang merupakan hasil percampuran dari Euthisianisme dengan Apolonarianisme dan Nestorianisme adalah Adopsionisme. Pengajaran sesat ini menyatakan bahwa kemanusiaan Kristus ada melalui adopsi, dengan demikian menolak dan menyangkal status diperanakan dari kemanusiaan Kristus.

Kristologi hasil skeptisisme Pencerahan, merupakan Kristologa yang memberontak terhadap Kristologi yang Ortodoks. Zaman pencerahan di Eropa, pada abad 17-18, merupakan abad kebangkitan rasio manusia dan membentuk suatu serangan frontal terhadap keyakinan tradisional gereja. Maksud dan tujuan utamanya adalah menyatakan otonomi akal manusia, supaya menggantikan pernyataan-pernyataan iman dengan dominasi rasio, menggantikan dogma dengan hasil-hasil ilmu pengetahuan, menggantikan yang supranatural dengan yang natural dan mengubah pandangan yang pesimistis tentang kondisi manusia dengan keyakinan pada kebaikan hakiki dari natur manusia yang mengakibatkan kemajuan sosial. Dalam serangannya terhadap Kekristenan, pencerahan juga menyerang pribadi Yesus. Bagi Pencerahan Yesus hanyalah seorang 'guru manusia'. Dalam buku 'Life of Jesus' yang sangat terkenal, yang ditulis oleh David Friedrich Strauss dan diterbitkan dalam dua volume setebal 1.480 halaman, dikemukakan bahwa, karena masalah integritas, dia tidak bisa mengkhotbahkan apa yang sebelumnyal dia yakini. Dia menulis dan membahas seluruh kitab Injil dengan terperinci, peristiwa demi peristiwa dan perumpamaan demi perumpamaan berdasarkan konsep 'mitos'nya dan menyebut semuanya sebagai legenda murni, walaupun ia percaya akan adanya kesadaran diri Mesianis dalam diri Yesus. Srauss langsung menjadi selebriti di tengan-tengah badai theologi, namun ini justru menghancurkan karirnya (John Stott; 2007).

Buku kedua, yang membicarakan tentang Kristologi hasil skeptisisme Pencerahan adalah, La vie de Jesus, karya Enns Renan (1863). Kritik terhadap Renan datang dari dua kelompok. Bagi kelompok Ortodoks, pemikiran Renan adalah bidat yang menyesatkan, bagi kaum Liberal, pengajarannya kurang liberal, namun yang pasti dia memang liberal. Renan menulis bahwa Sebagian dari kitab-kitab Injil berisi legenda sudah terbukti, sebab kitab-kitab itu penuh dengan mujizat dan hal-hal yang supranatural, (Ernst Renan, 1863/1904:12), sekalipun Yesus yakin Dia adalah Mesias, Dia bukanlah inkarnasi Allah ;kitab-kitab Injil "penuh dengan kesalahan dan konsep yang keliru" (Ernst Renan, 1863/1904:148); dan tidak ada kebangkitan yang sesungguhnya dari Kristus, dan mengatakan bahwa "kasih sayang dari seseorang yang begitu dikuasai halusinasi yang merujuk kepada Maria Magdalena, memberikan kepada dunia berita tentang Allah yang bangkit kembali”, (Ernst Renan, 1863/1904 : 144). Sesudah mengisahkan kematian 
Kristus, Renan berkata kepasa Yesus, "Beristirahatlah kini dalam kemuliaan-Mu, hai pemrakarsa yang mulia, karya-Mu telah usai; keilahian-Mu telah ditegakkan, selama ribuan tahun dunia akan menyanjung-Mu...antara Engkau dan Allah, manusia tidak bisa lagi membedakan," (Renan; 1983/1904). Namun, janganlah kita tertipu oleh jenis penghormatan retorik seperti ini, karena Renan sendiri telah menulis, "Sosok yang agung ini, boleh kita sebut ilahi, tidak dalam pengertian bahwa Yesus telah menyerap seluruh yang ilahi...melainkan dalam pengertian bahwa Yesus adalah sosok yang menyebabkan sesama-Nya manusia melakukan langka besar menuju yang ilahi "(Renan, 1963/1904: 151). Akhirnya, menurut Renan, Yesus hanyalah seorang manusia agung dan teragung, ketika ia berkata : "Maka, marilah kita menempatkan manusia Yesus di puncak tertinggi dari keagungan manusia, di antara orang-orang yang biasa-biasa saja pada umumnya umat manusia ; ada pilar-pilar yang menjulang ke langit, Yesus adalah yang tertinggi dari pilarpilar itu" (Renan; 1983/1904). Namun Yesus, tetap hanyalah manusia biasa.

Kristologi, Jumat Agung tanpa Paskah, adalah gambaran tentang Yesus Kristus yang dimulai di Spanyol dan kemudian mengembangkan bentuk khusus di seluruh Amerika Latin. Dalam buku klasik John A. Mackay, The Other Spanish Christ : A Study in the Spiritual History of Spain and South America (1932), diceriterakan bahwa Yesus yang diperkenalkan oleh ajaran Katolikisme Spanyol ke pada Amerika Latin adalah sosok tragedi, 'Kristus berdiri di hadapan kita sebagai korban yang tragis"(John A.Mackay; 1932). Para seniman agama Spanyol menggambarkan Kristus sebagai sosok yang 'memar, biru lebam, pucat dan berdarah', "Kristus yang dipelintir yang bergumul dengan kematian dan Kristus yang terbaring yang telah menyerah ke pada kematian...semuanya adalah inti dari tragedi yang mengerikan" (Mackay; 1932). Selanjutnya Mackay menulis, "Dia mati untuk selamanya, Dia telah menjadi inkarnasi dari kematian itu sendiri, Kristus ini tidak bangkit, ...mayat Kristus ini ...terbujur terlentang dan lurus bagaikan dataran, tanpa jiwa dan tanpa pengharapan, dengan mata terpejam menghadap ke langit ; dalam agama Spanyol, Kristus telah menjadi pusat dari penyembahan kepada kematian.”(Mackay, 1932 : 97). Setelah lima puluh tahun Mackay berada di Peru, Henri Nouwen berkunjung ke kota itu, dan keduanya seorang misionaris Presbiterian dan seorang imam Katolik Roma, memiliki kesimpulan yang sama. Dalam Jurnalnya Nouven menulis bahwa di gereja-gereja kota Lima, banyaknya penggambaran tentang Kristus yang menderita menimbulkan suatu kesan yang mendalam, lebih lanjut Nouven menulis:

Adalah sebuah altar besar yang dikelilingi oleh enam cela dinding di mana Yesus digambarkan dalam keadaan penderitaan yang berbeda : diikat pada sebuah tiang, tergeletak di lantai, duduk di atas sebuah batu, dan sebagainya, hampir selalu dalam keadaan telanjang dan diselimuti darah...Saya sama sekali tidak melihat adanya tanda-tanda kebangkitan pada semua gambar tersebut, tidak satupun yang mengingatkan saya kepada kebenaran bahwa Kristus mengalahakan dosa dan maut, dan bangkit dengan penuh kemenangan dari kubur. Semuanya adalah Jumat Agung, tidak ada Paskah...Penekanan yang hampir eksklusif pada tubuh Kristus yang teraniaya bagi saya merupakan pemutarbalikan terhadap Khabar baik menjadi suatu kisah yang mengerikan dan mengancam orang banyak namun tidak membebaskan mereka. (Henri Nouven,1983: 105)

Penggambaran tentang Kristus yang tidak berdaya yang popular di Amerika Latin, tentu tidak mendeskripsikan satu-satunya yang dikenal umat Kristen Amerika Latin. Tetapi menunjukan bahwa ada sebuah tradisi yang demikian, dimulai kaum mistik Spanyol abad ke enam belas yang dimulai oleh Raymond Lull. Menangagapi deskripsi tentang Yesus seperti itu, John Stott, menyatakan "Kita harus waspada terhadap ketidakseimbangan. Kita tidak memiliki kebebasan untuk memberitakan tentang bayi Yesus tanpa memberitakan 
kehidupan apa yang dituju oleh masa kanak-kanak tersebut; kita juga tidak memiliki kebebasan untuk memberitakan kehidupan dan kematiaan-Nya tanpa memberitakan kebangkitan-Nya yang mulia; kita juga tidak memiliki kebebasan untuk memberitakan Yesus yang historis dan objektif tanpa memberitakan pengabdian pribadi kepada Dia ; kita juga tidak memiliki kebebasan untuk memberikan penyembahan yang tradisionil, liturgis dan penuh hormat kepada-Nya tanpa memberitakan sukacita karismatik atau spontanitas apapun. Kita juga tidak boleh mengabaikan gambaran tentang Yesus sang pembebas, dengan seruan-Nya yang nyaring untuk kebebasan" (John Stott; 2007).

Kristologi Sosial Politik merupakan suatu usaha teologis/Kristologis untuk pembebasan sosial bagi kaum miskin di Amerika Latin dari struktur-struktur sosial politik yang menindas, dengan mengusung thema 'Teologia Pembebasan'. Pada era sekitar tahun 1970 di Amerika Latin, telah muncul berbagai theologi Liberasi, seperti 'Theology of hope' (1969) oleh Rubem Alves; 'A Theology of Liberation' (1971) oleh Gustavo Gutieres dan 'Operation-Liberation: a Callenge to Christian' (1972) oleh Hugo Assmann. Orlando Costas menggambarkan tiga serangkai theolog terkemuka diatas sebagai berikut: "Jika Alves adalah nabi dari gerakan itu dan Assmann adalah apologetnya, maka Gutieres adalah theolog Sistematikanya (Orlando Costas, 1974: 223). Dalam buku pertama Gutieres yang bersubjudul History, Politics and Salvation, diterangkan bahwa Amerika Latin adalah benua tertindas. Benar bahwa pada abad ke Sembilan belas republik-republik di Amerika Latin telah merdeka dari pemerintahan kolonial Spanyol dan Portugal, namun bangsabangsa tersebut tetap berada dalam belenggu politik dan ekonomi. Profesor Jose Migues Bonino dalam bukunya Doing Theology in a Revolutionary Situation (1975) menunjukkan bahwa Orang-orang Kristen memasuki Amerika Latin dalam dua tingkat yang berbeda namun sama-sama opresif, 'Kolonialisme bangsa Spanyol (Katolikisme Roma) dan neokolonialisme Atlantik utara (Protestantisme) (Jose Migues Bonino, 1975: xxiii). Sedangkan mantan uskup Agung katolik Roma di Brazil bagain timur, Dom Helder Camara menyebut adanya kolonialisme ketiga yakni 'kolonialisme internal' yakni penindasan politik dan ekonomi yang terus menerus oleh pemerintahan sayab kanan Amerika Latin sendiri yang hanya dipegang oleh segelintir orang saja dan oleh militer.

Awalnya theologia pembebasan ditujukan untuk penindasan sosial, politik dan ekonomi. Dalam penglihatan Gutieres, proses pembebasan dan perubahan merupakan usaha pencarian untuk memuaskan aspirasi-aspirasi manusia yang hakiki yakni kebebasan, martabat dan kemungkinan pemenuhan diri bagi setiap orang (Gustavo Gutieres; 1974). Willian $\mathrm{H}$. Lazareth mempertanyakan tentang eksistensi dan tujuan dari theologi pembebasan seperti berikut ini "Isu yang sangat penting bagi theologia pembebasan adalah relasi antara kebebasan Kristen dan kebebasan politik. Dengan otoritas rasuli apakah kita boleh mencampurkan pembebasan dari dosa, maut dan si jahat dengan pembebasan dari ketidakadilan, penindasan dan kemiskinan? Dalam pengertian yang lebih pribadi, bagaimana kita menghubungkan aktivitas Yesus dan Paulus pada abad pertama dengan aktivitas Che Gevaro dan Camilo Torres pada abad kedua puluh? Apakah kedua aktivitas ini serupa, merupakan pengulangan, bisa dibedakan atau tidak berhubungan? (Bonino; 1975).

Perlu diperhatika bahwa salah satu ciri dari theologia pembebasan adalah aksentuasinya pada praksis (penerapan) sebagai metode baru dalam berteologi. Menurut Gutieres, langka utama dalam 'bertheologia' bukan membuka Alkiatab, tetapi berkomitmen serius untuk berjuang demi pembebasan, karena teks pertama yang harus dipelajari bukan teks Alkitab, melainkan teks sosial, yaitu realitas disekitar kita dan pengalaman kita akan realitas itu, sesudah itu, siaplah bagi kita untuk langka kedua yakni studi Alkitab. Karena itu theologia diartikan sebagai 'suatu refleksi kritis tentang praksis Kristen dalam terang Firman (Gutieres; 1974). Andrew Kirk mengkritisi hermeneutik 
theologi Pembebasan sebagai berikut: "Tidak satupun dari para penulis ini yang melakukan studi eksegetis terhadap perikop yang popular yang dijelaskan...kebanyakan tidak berusaha menguji secara eksegetis kebenaran dari metode maupun penggunaan teks mereka sendiri. (J.A. Kirk; 1979). Kalau kita memperhatikan penggunaan tema 'Eksodus'oleh golongan Liberal, maka menjadi jelas, bahwa hal itu dianggap sebagai suatu paradigma untuk setiap penyelamatan dari penindasan, tanpa melihatnya sebagai suatu perbuatan Allah yang besar yang merupakan penggenapan kovenan, dimana Allah mengingat dan menggenapi kovenannya dengan Abraham, Ishak dan Yakub (Keluaran $2: 24)$.

Uskup K.H.Ting dari Shanghai, presiden dari China Christian Council mengkritisi kelonggaran hermeneutik theologi pembebasan dengan menegaskan: "Theologi Pembebasan adalah hal yang baik, sehingga kita merasa berat hati, karena tidak sanggup mendukung keseluruhannya", karena "tema kekal dari keKristenan dan Theologi seharusnya bukan bersifat politik...melainkan pendamaian manusia dengan Allah...pendamaian antara Allah dan manusia merupakan thema kekal dari theologi Kristen" (K.H.Ting; 2000). Pada tahun 1974 Kongres Lausane berbicara terus terang tentang masalah ini juga. Berikut adalah tanggapan kaum Injili dalam tema "tanggung jawab sosial orang Kristen":

Kami menegaskan bahwa Allah adalah Pencipta dan sekaligus Hakim atas semua manusia. Karena itu, kita harus berbagi kepedulian-Nya terhadap keadilan dan rekonsiliasi di seluruh masyarakat manusia dan terhadap pembebasan manusia dari segala jenis penindasan. Karena umat manusia dijadikan menurut gambar Allah, setiap orang-tidak peduli ras, agama, warna kulit, budaya, kelas, jenis kelamin atau usia-memiliki martabat yang tertanan di dalam dirinya, maka dia harus dihormati dan dilayani, bukan dieksploitasi. Di sini juga kami menyatakan penyesalan atas ketidakpedulian kami dan karena adakalanya menganggap penginjilan dan kepeduliaan sosial merupakan dua hal yang terpisah. Sekalipun rekonsiliasi dengan manusia bukanlah rekonsiliasi dengan Allah, bukan penginjilan tindakan sosial, bukan pula keselamatan liberasi politik, kami menegaskan bahwa baik penginjilan maupun keterlibatan sosial politik, keduanya merupakan bagian dari kewajiban Kristen kita karena keduanya merupakan ungkapan yang niscaya dari doktrin-doktrin kita tentang Allah dan manusia, kasih kita terhadap sesama kita dan ketaatan kita kepada Yesus Kristus (John Stott, 1996: 24-27 )

Jadi, berdasarkan pemaparan-pemaparan tersebut diatas, maka dapat disimpulkan bahwa: (1) Pengajaran Ebionit hakikatnya adalah menyangkal keilahian Kristus, (2) pengajaran Gnostisisme hakekatnya adalah menyangkal kemanusiaan Kristus, (3) Arianisme hakekatnya adalah Kristus hanyalah makhluk ciptaan, (4) Apolonarianisme hakekatnya adalah menyangkali kepenuhan kemanusiaan Kristus, (5) Nestorianisme hakekatnya adalah menyangkal kesatuan dua hakikat di dalam Kristus, mereduksi-Nya menjadi manusia yang dipenuhi dengan Allah, (6) Euthisianisme hakekatnya adalah menyangkal perbedaan anatara dua hakikat Kristus,

Lalu membentuk hakikat yang ketiga atau cangkokan dari dua hakekat tersebut, (7) Monofisitisme hakikatnya adalah menyangkal dua hakekat dan kehendak di dalam satu pribadi Kristus, Kristus yang ilahi saja yang dipercaya sebagai hasil percampuan dari kedua sifat Kristus tersebut, (8) Kristologi hasil skeptissime pencerahan, hakekatnya adalah memaparkan Kristus, hanya sebagai manusia biasa saja,walaupun manusia teragung,tetapi tetap saja sebagai manusia pada umumnya, yang walaupun memiliki sifat keilahian, tetapi tidak sepenuhnya dan tidak sempurna sebagai yang ilahi, (9) Kristologi Jumat Agung tanpa Paskah, hakekatnya adalah menyatakan tentang Kristus yang 
menderita sengsara seperti yang terjadi pada peristiwa Jumat Agung, tetapi Kristus yang telah bangkit dari kematian dalam kemenangan tidak disampaikan secara pasti sebagaimana terjadi pada hari Paskah dan (10) Kristologi Sosial Politik hakekatnya adalah usaha pembebasan kaum miskin dari struktur sosial yang menindas mereka, walaupun memakai terninologi dan konsep-konsep Kristen yang sudah dipolitisir.

Berhubung Ajaran-ajaran sesat begitu gencar menyerang Kekristenan yang Alkitabiah dan sekaligus merongrong iman gereja yang sejati, maka berbagai dewan gereja telah berkumpul secara berkala untuk merumuskan dan menyatakan pengakuan iman bersama berlandaskan Alkitab, dalam upaya untuk memelihara dan menjaga 'iman yang telah disampaikan kepasa orang-orang kudus'. (Yudas 1:3). Berikut adalah rumusan pengakuan Iman yang dikerjakan oleh Konsili/Dewan gereja, pada tahun $451 \mathrm{M}$ di Kalsedon:

Mengikuti bapa-bapa suci, kami semua dengan satu kesepakatan mengajarkan dan mengakui akan satu Anak yang sama, Tuhan kita Yesus Kristus, sama-sama sempurna di dalam kemanusiaan-Nya, Allah yang sesungguhnya dan manusia yang sesungguhnya, akan jiwa yang berakal dan bertubuh, akan substansi yang sama dengan Bapa dalam keilahian-Nya, akan substansi yang sama dengan kita dalam kemanusian-Nya, dalam segala sesuatu seperti kita, kecuali dosa, sebelum dunia dijadikan, diperanakkan dari Bapa dalam keilahian-Nya, tetapi dikemudian hari bagi kita dan bagi penebusan kita, diperanakkan (yang sama) dari perawan Maria, bunda Allah, dalam kemanusianNya, satu Kristus, Anak dan Tuhan yang sama. Anak yang tunggal yang mengambil wujud dalam dua hakekat, tanpa kekacauan, tanpa perubahan, tidak dapat dibagi, tidak dapat dipisahkan. Perbedaan dari hakikat-hakikat sama sekali tidak dihilanghkan oleh kesatuan tersebut, tetapi sebaliknya sifat masing-masing hakikat dipelihara dan digabungkan dalam satu pribadi dan satu hipostase; bukan satu pribadi yang terpisah atau terbagi dalam dua pribadi, tetapi satu Anak yang sama dan tunggal, yakni Allah, Logos dan Tuhan Yesus Kristus.”(Kevin J. Conner, 2004 : 363364).

\section{Adanya Spirit Dan Sifat Satanisme Yang Menyesatkan, Mendustai Dan Memurtadkan}

Alkitab memperingatkan gereja bahwa pada masa akhir zaman, akan muncul ajaran atau doktrin setan-setan. Rasul Paulus, mengigatkan Timotius: 'Roh dengan tegas mengatakan bahwa di waktu-waktu kemudian, ada orang yang akan murtad lalu mengikuti roh-roh penyesat dan ajaran setan-setan...' (1 Timotius 4:1-3; 1 Korintus 10:20-21). Ajaran atau doktrin setan-setan ini diadakan, dikembanghkan dan disebarkan oleh orangorang yang tersesat seperti sudah disebutkan sebelumnya. Rasul Paulus menyinggung tentang orang-orang yang 'mencari keuntungan dari Firman Allah,'yakni mereka yang memahami firman Allah secara tidak murni dan tidak benar (2 Korintus 2:17). Ular sebagai wujud setan berbicara kepada Hawa dan memutarbalikan Firman Allah, sehingga mengakibatkan kejatuhan manusia ke dalam pelanggaran dan dosa. Tipu daya adalah senjata utama Setan di taman Eden (Kejadian 3:1-6), dan ini juga adalah senjata setan di zaman akhir ini. Matius 24:4,11,24, mengingatkan tentang tipu daya yang akan terjadi di zaman akhir. Paulus juga dalam Efesus 4:14 berbicara tentang angin-angin pengajaran dan kecurangan manusia, kelicikan mereka untuk menyesatkan orang-orang yang lemah. Inilah awal mula dari pengajaran sesat, yang muncul dari pengaruh setan-setan dan tersebar melalui manusia-manusia-manusia sesat.

Rasul Petrus mengatakan hal yang sama, ketika sang rasul berbicara tentang orangorang yang tidak paham dan tidak teguh imannya, yang memutarbalikan kebenaran Alkitab 
menjadi kebinasaan diri mereka sendiri (2 Petrus 3:14-16). Istilah 'memutarbalikan' berarti 'merenggut atau meyiksa' sehingga menyesatkan dan membengkokkan kebenaran Alkitab yang mereka juga mengakuinya sebagai pengajaran (Keluaran 23:6; Ulangan 16:19; Mazmur 56:5). Alkitab menegaskan bahwa penghukuman kekal diberikann kepada semua orang yang 'menanbah' atau 'mengurangi' Firman Allah. Mereka akan mengalami murka yang kekal dari Allah. (Ulangan 4:2; Amos 30:6; Wahyu 22:18-19). Rasul Paulus menyatakan kutukan atas malaekat atau peyesat-penyesat yang memberitakan 'Injil yang lain' (Galatia 1:6-8). Para penganjur ajaran sesat umumnya mengajarkan 'Yesus yang lain', menerima dan menyalurkan 'roh yang lain'dan menyuarakan 'injil yang lain' (2 Korintus 11:4). Setiap ajaran, akhirnya berasal dari salah satu dari dua kemungkinan sumbernya yakni dari Roh kebenaran atau dari roh dusta. Setiap pengajar memberitakan salah satunya, menurut Roh yang ada pada mereka dan yang mempengaruhinya. Pada harihari terakhir, sekarang ini setan sedang menyerang gereja melalui pikirannya yang dinyatakan dalam doktrin roh jahat, untuk menipu manusia. Kondisi dan situasi seperti ini, menuntut kebutuhan akan doktrin yang benar dan sehat dari Kristus dan firman-Nya Alkitab. Berikut daftar perbandingan doktrin Kristus dan Setan:

DOKTRIN ALLAH/KRISTUS
Roh Kebenaran
Terang
Doktrin Allah
Doktrin Kristus
Doktrin rasul-rasul
Percaya
Kehidupan dan kebebasan

\author{
DOKTRIN SETAN/IBLIS \\ Roh Dusta/kepalsuan \\ Gelap \\ Doktrin setan \\ Doktrin roh-roh jahat \\ Doktrin manusia \\ Tipu daya \\ Perbudakan dan kematian.
}

Rasul Paulus menasehati Timotius, untuk selalu siaga dalam menghadapi ajaranajaran sesat yang diispirasi dan dimotori oleh roh-roh jahat yang berkembang di dalam dan disekitar jemaat Efesus yang digembalakannya (2 Tomotius 2:14-26). Karena penyelewengan doktrin selalu membawa konsekwensi penyesatan intelektual, kemerosotan iman dan dekadensi moral. Sebagai lanjutan dari penjelasanya Paulus sebelumnya, dalam 2 Timotius 3:1-5, Paulus merinci delapan belas ciri dari kemorosotan moral para bidat, yakni : mencintai dirinya sendiri (egoisme pribadi dan kelompok seperti yang ada pada bidat) ; menjadi hamba uang (dikusai oleh roh materialisme seperti yang ada pada spirit bidat) ;menyombongkan diri (menganggap diri dan kelompoknya paling benar sendiri); menjadi pemfitna (menyebarkan fitnah tentang kebenaran Allah dan firman-Nya seperti yang ada pada bidat ); berontak terhadap orang tua (atas alasan ajaran sesat yang ada pada mereka); tidak mau berterima kasih (kepada keselamatan di dalam Kristus yang sudah tersedia dan membuat jalan keselamatan sendiri versi bidat)); tidak memperdulikan agama (menentang agama yang benar dan resmi , dan membuat aliran agama versi sendiri) ; tidak tahu mengasihi (orang-orang yang berbeda ajaran dan keyakinan denggan mereka); tidak mau berdamai (dengan pihak dan kelompok yang menegakkan ajaran yang benar dari Alkitab); suka menjelekkan orang (yang menegur, mengoreksi kesalahan dan kekeliruan doktrin mereka); tidak dapat mengekang diri (reaktif dan agresif terhadap teguran dan disiplin yang ditujukan kepada mereka); garang dan tidak suka yang baik (menentang dan melawan ortodoksi yang sudah disepakati ); suka berkhianat (terhadap kesepakatan yang telah disetujui bersama); tidak berfikir Panjang (terhadap konsekwensi-konsekwensi jangka panjang atas perlawanannya); berlagak tahu (mengenggap diri dan kelompoknya lebih benar dan pintar dari kelompok lain) ; lebih menuruti hawa nafsu daripada menuruti Allah (kebenaran Allah dikesampingkan atas nama nafsu golongan dan ajarannya sendiri); 
menjalankan ibadah secara lahiriah tetapi hakekatnya mengangkal kuasa Allah (ibadah dijadikan jubah penutup kepalsuan dan dan kemunafikan ). Sehingga dapat dikatakan bahwa karakter dan spirit seperti tersebut di atas, sudah menjadi pemandangan umum para penganut dan pengikut ajaran-ajaran sesat di dalam sejarah kekristenan. Pertanyaannya adalah siapa dan apa dibakik dan di dalam semuanya ini? Jawabannya adalah pasti dan benar, yakni roh-roh setan yang sangat memusuhi Allah, Firman Allah dan umat Allah yang sejati.

\section{SIMPULAN}

Untuk menyimpulkan pokok-pokok bahasan tersebut diatas, saya mengutip apa yang dikatakan oleh Theolog Injili yang termasyur pada dekade ini, yakni John Stott. Ketika menulis tentang 'Kristus mengalahakan Iblis dan para pengikutnya'berdasarkan Wahyu 12-13, beliau menyatakan sebagai berikut:

"kitab wahyu membiarkan kita mengintip di belakang layar dan melihat strategi Iblis yang begitu licik. Kita bisa melihat bagaimana dia pada pasal-pasal awal kitab Para Rasul juga menggunakan tiga senjata yang sama. Pertama dia berusaha melumat jemaat dengan paksaan; kedua, dia berusaha membuat bobrok jemaat dengan kemunafikan Ananias dan Safira; ketiga, dia berusaha menyesatkan jemaat dengan ajaran palsu, mengalihkan perhatian para rasul dari pelayanan Firman mereka dan dengan demikian mengarahkan jemaat kepada bidat. Diseluruh dunia hari ini, serangan lapis tiga yang sama terhadap jemaat tetap dilanjutkan oleh Iblis - jasmani (penganiayaan), moral (kompromi), dan intelektual (ajaran sesat)" (John Stott; 2007).

Oleh karena itu, mengantisipasi muncul dan berkembangnya ajaran-ajaran sesat/ bidat-bidat, pertama-tama gereja harus menjaga kemurnian pengajarannya (ortodoksi dan ortopraksis) dari pengaruh sistim hidup lama anggota-anggota gereja, terutama para tokohnya. Dalam hal ini, pihak gereja perlu mendisiplin dan menghentikan guru-guru palsu yang memalsukan Injil. Gereja bertanggung jawab penuh atas kemurnian pengajaran dari rongrongan bidat-bidat (1Timotius 1:3-11, 18-20; Galatia 1:6-10). Kristus telah memberi wewenang kepada gereja-Nya untuk mengikat dan melepaskan (Matius 16:19; 18:18; Yohanes 20:23). Wewenang itu teraplikasi dalam disiplin gereja dan juga disiplin terhadap guru-guru palsu yang menganjurkan ajaran-ajaran sesat; mereka dapat diberhentikan (Titus $3: 10$; 1Tomotius 6:4-10), karena dibelakang dan didalam aktivitas serta pengajaran mereka, jelas ada kegiatan roh-roh setan yang menyesatkan. Siapa yang mau disesatkan, penyesatlah yang harus dipukul mundur dari dalam pengajaran dan iman gereja. Kedua, Sikretisme (kompromi) yaitu percampuran unsur-unsur filsafat dan agama-agama kafir dengan pengajaran Iman Kristen, harus selalu diwaspadai, disikapi dan diatasi secara saksama. Karena penjelasan pengajaran Kristen yang menggunakan istilah dan konsep filsafat dan agama dunia, mengandung bahaya dan pengaruh yang sinifikan, yang selalu perlu dijaga supaya tidak sampai mengorbankan hakekat dan isi utama pengajaran murni iman Kristen. Batas-batasnya, proporsinya dan kriterianya harus jelas dan ketat (1Yohanes 4:1-4). Ketiga, ketidakpuasan dan kekecewaan orang-orang Kriten terhadap kerohanian/spiritual gereja, baik menyangkut ajaran dan praktiknya, dapat dijawab dengan : (1) Gereja perlu menjabarkan kembali pengajaran Akitab yang utuh tentang Roh Kudus, karunia-karunia-Nya serta buah Roh secara relevan dan aktual, (2) demikian juga pengajaran Alkitab tentang Eskatologi, perlu diterangkan lagi secara seimbang dan proporsional, agar orang-orang Kristen, memiliki batang pengukur atau filter dalam menghadapi ajaran-ajaran sesat di sekitar dan di dalam isu-isu kedatangan Kristus kembali, dan (3) Hubungan antara perkembangan organisasi gereja dengan organisme gereja dalam praktek hidup dan ibadah, sangat perlu diterangkan dengan baik dan benar, supaya seimbang dan proporsional seperti yang diajarkan Alkitab. Misalnya tentang peranan dan 
fungsi rohaniwan dan kaum awam di dalam gereja, itu perlu dimengerti dengan baik dan seimbang secara Alkitabiah. Contohnya dapat dilihat dalam praktek hidup dan ibadah gereja rasuli. Karena kerinduan adanya suatu gereja yang berpolakan gereja Perjanjian Baru, sangat kuat berkembang di dalam hati orang-orang Kristen yang sudah lahir baru. Sebab jika tidak, maka biasanya orang-orang itu akan mencari gereja lain yang mereka anggap sesuai dan coccok atau malahan mereka nekat mendirikan gereja baru sesuai dengan selera dan versi mereka sendiri. Dalam situasi dan kondisi seperti ini, tidak jarang mengakibatkan munculnya gereja dengan ajaran-ajaran yang menyimpang. Keempat, Gereja sendiri dalam menghadapi pengaruh dan ikatan "materialism", sangat penting untuk menentukan sikap teologis yang benar terhadap materi atau kekayaan, karena dampak dari roh materialisme terhadap gereja telah dan selalu melumpuhkan gereja sendiri dari dalam, artinya diluar kelihatan mengkilap atau mentereng padahal di dalamnya sudah rapuh dan keropos. Untuk maksud itu perlu memberlakukan prinsip 'kekayaan adalah berkat Allah yang berasal dari Allah yang wajib dipakai untuk melayani Alllah, sesama dan diri sendiri. Kekayaan itu sendiri haruslah menjadi hamba dan pelayan Allah dan orang-orang Kristen dan bukan sebaliknya, menjadi tuan dan majikan yang memperhamba kita. (1Korintus 6:12). Karena itu, jangan pernah menjadikan kekayaan atau harta itu untuk melayani setan, ajaran-ajaran sesat, hawa nafsu dan tujuan-tujuan apapun yang bertentangan dengan kehendak Allah. Kelima, Menyadari adanya kehadiran, aktivitas serta penyesatan roh-roh setan di dalam dan melalui ajaran-ajaran sesat, maka hal itu penting untuk diantisipasi, disikapi dan dibendung serta dilawan dengan kuasa dan hikmat Roh Kudus dan firman Allah melalui ajaran-ajaran yang ortodoks seperti yang sudah dirumuskan, ditegakkan dan dipertahankan oleh konsili-konsili gereja selama berabad-abad. Keenam, dengan memahami karakteristik ajaran sesat seperti menyelewengkan doktrin Allah Tritunggal yang kudus, memutarbalikan doktrin Kristologi yang Alkitabiah dan ditambah dengan dampak buruk yang merusak dan menghancurkan intelektual, moralitas serta iman Kristen, maka wajib bagi kita untuk bertindak, menginternalisasi dan mensosialisasi ajaran-ajaran benar (Ortodoksi dan Ortopraksis) secara konkrit, terencana dan kontinyu sampai menjadi agenda utama program pengajaran gereja-gereja di Indonesia. Dalam hal ini, gereja wajib berjuang sedemikian rupa sampai memenangkan perjuangan dan peperangan rohani ini bersama Kristus dan Firman-Nya Alkitab, supaya penyelewengan dan penyesatan dapat dipukul mundur (1Korintus 15:58; Galatia 2:4-5). Ketujuh, Mereka yang telah tersesat karena tertipu ajaran sesat, terikat oleh belenggu roh setan dan rusak moralitasnya, wajib dibawah pulang dan digabungkan kembali ke dalam kebenaran Kristus yang memerdekakan (Yohenes 8:30-32), agar mereka menjadi bagian integral lagi dari "tubuh Kristus" yang am dan universal. Karena itulah yang dikehendadi Kristus bagi dombadomba yang telah tersesat dan terhilang. Semoga Tuhan Allah di dalam Kristus, menolong kita dalam perjuangan rohani ini.

\section{DAFTAR PUSTAKA}

Aritonang Jan S. 2000. Berbagai Aliran di dalam dan di Sekitar Gereja. Jakarta; BPK Gunung Mulia

Bonino Jose Migues. 1975. Doing Theology in a Revolutionary Situation. London: Fotress Press

Berkhof H and Enklaar. 2000. Sejarah Gereja. Jakarta: BPK.Gunung Mulia Corner J Kevin.2004. Pedoman Praktis tentang Iman Kristiani. Malang: Gandum Mas Daun Paulus.1990. Bidat Kristen dari masa ke Masa. Manado: Yayasan Daun Family Douglas. 1974. The New International Dictionary of Christian Church. Grand Rapid: Zondervan Publisher 
End Van Den Thomas. 1985. Harta dalam Bejana. Jakarta: BPK. GM

Gutieres Gustavo. 1974. A Theology of Liberation: History, Politic and Salvation. London : Cambridge University Press

Harrison E.F.1960. Bakker's Dictionary of Theology. Grand Rapid Michigan: Baker Book House

Kirk J.A. 1979. Liberation Theology: An Evangelical View from the third World. London: Marshall Morgan and Scott Press

Knee E. Stuert. 1994. Christian Science in the age of Marry Bakker Eddy. West Port and London: Green Wood Press

Kuhl Diertich. 1992. Sejarah Gereja Mula-mula. Batu Malang: YPPIIB

Mackay A. John. 1932. The Other Spanish Christ: A study in the Spiritual History of Spain And South Amerika. Lima Peru: Peru's National University Press

Naisbitt John and Aburdene Particia. 2000. Megaterends. Jakarta: Binarupa Aksara

Nouven Henri. 1983. Gracias: A Latin American Journal. Orbis Publishing

Prince Derek. 2000. Mereka akan Mengusir Setan-setan. Jakarta: YPII

Pringgodigdo A.G. and Hassan Shadily. 1976. Ensiklopedi Umum. Yogyakarta: Yayasan Kanisius

Subagio A. Andreas. 2004. Pengantar Riset Kuantitatif dan Kualitatif. Bandung: Kalam Hidup.

Stott John. 2007. Kristus yang Tiada Tara. Surabaya: Momentum

Stott John. 1969. The Epistle of John dalam Tyndale New Testament Commentaries. Grand Rapid Michigan: William B. Eermans Publishing Company

Stott John.ed., 1996. Making Christ Known: History Mission Document from the Lausane Movement, 1974-1989. London: Paternoster Press

Ting K.H. 2000. Love never Ends. Shanghai: Nanjing Seminary Press Tong Stephen. 1977. Roh Kudus, Suara Hati dan Setan. Jakarta: LRII Verkuyl J. Gereja dan Bidat-bidat. Jakarta: BPK.Gunung Mulia 